The

University

of Chicago

Law Review

\title{
The Comedy of the Commons: Custom, Commerce, and Inherently Public Property
}

\author{
Carol Rose†
}

\section{Introduction: The Conundrum of "Public Property"}

The right to exclude others has often been cited as the most important characteristic of private property. ${ }^{1}$ This right, it is said, makes private property fruitful by enabling owners to capture the full value of their individual investments, thus encouraging everyone to put time and labor into the development of resources. ${ }^{2}$ Moreover, exclusive control makes it possible for owners to identify other owners, and for all to exchange the fruits of their labors, until these things arrive in the hands of those who value them

$†$ Professor of Law, Northwestern University. I have foisted earlier versions of this paper on numerous patient friends and colleagues. For their helpful comments and criticism, I particularly thank Jonathan Entin, Victor Goldberg, Mark Grady, Hendrik Hartog, Henry Hansmann, Richard Helmholz, William Marshall, Thomas Merrill, Stephen Presser, George Priest, and the indefatigable Cass Sunstein.

12 William Blackstone, Commentaries *2 (property defined as "that sole and despotic dominion . . . over the external things of the world, in total exclusion of the right of any other individual in the universe"); see also Loretto v. Teleprompter Manhattan CATV Corp., 458 U.S. 419, 435 (1982) (the right to exclude is the most valuable element of property).

22 W. Blackstone, supra note 1 , at *4 (no one would devise conveniences to make life more "agreeable" unless s/he could keep them permanently); id. at *7 ("who would be at the pains of tilling [the earth] if another might ... seise upon and enjoy the product of his industry, art, and labour?"). 
most highly-to the great cumulative advantage of all. ${ }^{3}$ Thus exclusive private property is thought to foster the well-being of the community, giving its members a medium in which resources are used, conserved and exchanged to their greatest advantage. There is nothing new about this set of ideas; Richard Posner, a modernday proponent of neoclassical economics, remarks that the wealthenhancing value of property rights "has been well known for several hundred years." 4 Posner cites Blackstone for this proposition," and indeed, since the advent of eighteenth-century classical economics, it has been widely believed that the whole world is best managed when divided among private owners. ${ }^{6}$

The obverse of this coin is the "tragedy of the commons." When things are left open to the public, they are thought to be wasted by overuse or underuse. No one wishes to invest in something that may be taken from him tomorrow, and no one knows whom to approach to make exchanges. All resort to snatching up what is available for "capture" today, leaving behind a wasteland. From this perspective, "public property" is an oxymoron: things left open to the public are not property at all, but rather its antithesis.

${ }^{3}$ Holderness, A Legal Foundation for Exchange, 14 J. LEGal Stud. 321, 321-22, 344 (1985) (narrow and specific assignment of rights necessary for exchange).

4 Richard Posner, Economic Analysis of Law 28 (2d ed. 1977). Posner is speaking here only of property as an inducement to good management, but points out the importance of transferability a few paragraphs later. See id. at 28-29.

s Id. at 28 n.3 (citing 2 W. Blackstone, supra note 1, at *4, *7); Blackstone also praises "that wise and orderly maxim, of assigning to every thing capable of ownership a legal and determinate owner." $2 \mathrm{~W}$. BlackstonE, supra note 1 , at * 15 .

- See, e.g., Jeremy Bentham, The Theory of Legislation, Civil Code pt. 1, chs. 7-9 (Ogden ed. 1931). The great 18th-century economist Adam Smith also mentioned in passing that it is only where no one has anything worth more than two or three days' labor that there is no need to protect private property. ADAM SMITH, THE WEALTH of NATIONS 669-70 (Modern Library ed. 1937). See also Joseph Angell, A Treatise on the Right of Property In Tide Waters and in The Soll and Shores Thereof 17 (1826), where this American jurist follows Blackstone in arguing that all things capable of ownership should be assigned an owner, with those things incapable of exclusive ownership being assigned to the sovereign. For a modern statement of this idea, see Yandle, Resource Economics: A Property Rights Perspective, 5 J. ENergy L. \& PoL'Y 1, 1-2 (1983) (natural progression toward individual ownership of scarce resources). For a challenge to the view that private ownership is presumptively the most efficient form of management, see Kennedy \& Michelman, Are Property and Contract Efficient?, 8 Horstra L. REv. 711 (1979-80).

3 The phrase and the classic modern statement of the position come from Hardin, The Tragedy of the Commons, 162 ScIEncE 1243 (1968), reprinted in Economic Foundations of Property LAW 2 (B. Ackerman ed. 1975).

B Id.; see also Holderness, supra note 3, at 344 ("ordinary forms of social interaction, both within and beyond trade and commerce, could not take place if property rights were inconsistent or ill defined"). 
Thus it is peculiar to find a longstanding notion of "public property" in the law of the western world. The Romans, whose legal thinking greatly influenced later European law, were sufficiently interested in "public property" to separate it into at least four categories. ${ }^{9}$ And despite the power of the classical economic argument for private property, a curious cross-current has continually washed through American law. Our legal doctrine has strongly suggested that some kinds of property should not be held exclusively in private hands, but should be open to the public or at least subject to what Roman law called the "jus publicum": the "public right."10

Moreover, this view is not merely a vestige of premodern thought; there is currently an extensive academic and judicial discussion of the possibility that certain kinds of property ought to be public. In recent years, the most striking version of this "inherent publicness" argument has appeared in a series of cases expanding public access to waterfront property. ${ }^{11}$ The land between the low and high tides has traditionally been considered "public property," or at least subject to a public easement for navigational and fishing purposes. ${ }^{12}$ But some modern courts have stretched this easement to include a new use-recreation-and have expanded its area from the tidelands to the dry sand areas landward of the high-tide

- For the Roman law categories of public property, see Coquillette, Mosses from an Old Manse: Another Look at Some Historic Property Cases about the Environment, 64 Connell L. Rev. 761, 801-03 (1979); MacGrady, The Navigability Concept in the Civil and Common Law, 3 FLA. ST. U.L. Rev. 511, 518 (1975). For applications of these classifications, see Deveney, Title, Jus Publicum, and the Public Trust: An Historical Analysis, 1 SeA Grant L.J. 13, 29-36 (1976); Wiel, Natural Communism: Air, Water, Oil, Sea, and Seashore, 47 HaRv. L. Rev. 425 (1934); Winett, Contemporary Water Pollution Cases and Roman Law, III Temp. EnvtL. L. \& Tech. J. 31 (1984).

10 This has been argued forcefully by Molly Selvin and Harry Scheiber, whose recently published historical studies argue that 19th-century American law was replete with notions of "public rights," some of which were characterized as property rights. Scheiber, Public Rights and the Rule of Law in American Legal History, 72 CAL. L. REv. 217 (1984); Selvin, The Public Trust Doctrine in American Law and Economic Policy, 1789-1920, 1980 WIs. L. REv. 1403. For the "jus publicum" (or "publici juris") language, see Deveney, supra note 9, at 29-31; see also Commonwealth v. Alger, 61 Mass. (7 Cush.) 53, 76 (1851), discussed in Scheiber, supra, at 222.

11 See, e.g., City of Berkeley v. Superior Court, 26 Cal. 3d 515, 606 P.2d 362, 162 Cal. Rptr. 327, cert. denied, 449 U.S. 840 (1980); Gion v. Santa Cruz, 2 Cal. 3d 29, 465 P.2d 50, 84 Cal. Rptr. 162 (1970); Borough of Neptune City v. Borough of Avon-by-the-Sea, 61 N.J. 296, 294 A.2d 47 (1972); State ex rel. Thornton v. Hay, 254 Or. 584, 462 P.2d 671 (1969); Seaway Co. v. Attorney General, 375 S.W.2d 923 (Tex. Civ. App. 1964).

${ }_{12}$ See, e.g., Martin v. Waddell, 41 U.S. (16 Pet.) 366, 412-14 (1842); cf. MacGrady, supra note 9 , at 566-68 (the "public" character of this land is a creation of the 17 th and 18th centuries). 
mark. ${ }^{13}$

These new cases extrapolate from older precedents in which the public acquired-or allegedly reasserted-claims to certain types of property, most notably roadways and lands under navigable waters. Like the older precedents, the new beach cases usually employ one of three theoretical bases: (1) a "public trust" theory, to the effect that the public has always had rights of access to the property in question, and that any private rights are subordinate to the public's "trust" rights; ${ }^{14}(2)$ a prescriptive or dedicatory theory, by which a period of public usage gives rise to an implied grant or gift from private owners; ${ }^{16}$ and (3) a theory of "custom," where the public asserts ownership of property under some claim so ancient that it antedates any memory to the contrary. ${ }^{16}$

These theories of increased public access to shores and waterways have garnered a vocal but decidedly mixed reaction. In discussing these theories, some commentators applaud what they regard as a proper recognition of public needs. ${ }^{17}$ The public trust

13 See, e.g., Gion, 465 P.2d 50; City of Daytona Beach v. Tona-Rama, Inc., 294 So. 2d 73 (Fla. 1974); Van Ness v. Borough of Deal, 78 N.J. 174, 393 A.2d 571 (1978); Thornton, 462 P.2d 671; Seaway Co., 375 S.W.2d 923.

14 See, e.g., State v. Superior Court, 29 Cal. 3d 210, 625 P.2d 239, 172 Cal. Rptr. 696 (inland waterfront), cert. denied, 454 U.S. 865; City of Berkeley, 606 P.2d 362; Van Ness, 393 A.2d 571; Borough of Neptune City, 294 A.2d 47; Matthews v. Bay Head Improvement Ass'n, 95 N.J. 306, 471 A.2d 355, cert. denied, 105 S. Ct. 93 (1984); Just v. Marinette Country, 56 Wis. 2d 7, 201 N.W.2d 761, 768-69 (1972) (public trust in shoreland of navigable waters). For commentary, see Deveney, supra note 9; Note, The Public Trust in Tidal Areas: A Sometime Submerged Traditional Doctrine, 79 YaLE L. J. 762 (1970) [hereinafter cited as Note, Tidal Areas]; Note, Public Beach Access Exactions: Extending the Public Trust Doctrine to Vindicate Public Rights, 28 UCLA L. REv. 1049, 1069-86 (1981) (prefers public trust to alternate theories of public access) [hereinafter cited as Note, Beach Access].

${ }_{18}$ Perhaps best known of these cases is California's Gion, 465 P.2d 50. Other states in which courts have recently applied the "implied dedication" or prescriptive approach to the waterfront are Texas, in Seaway Co., 375 S.W.2d 923, and-somewhat reluctantly-New York, in Gewirtz v. City of Long Beach, 69 Misc. 2d 763, 330 N.Y.S.2d 495 (Sup. Ct. 1972), aff'd, 45 A.D.2d 841, 358 N.Y.S.2d 957 (1974) (mem.). Cf. Department of Natural Resources v. Mayor of Ocean City, $274 \mathrm{Md}$. 1, $332 \mathrm{~A} .2 \mathrm{~d} 630$ (1975) (doctrine held inapplicable because no clear intent to dedicate); State v. Beach Co., 271 S.C. 425, 248 S.E.2d 115 (1978) (no intent to dedicate). For commentary, see, for example, Livingston, Public Access to Virginia's Tidelands: A Framework for Analysis of Implied Dedications and Public Prescriptive Rights, 24 WM. \& Mary L. REv. 669 (1983); Comment, Public or Private Ownership of Beaches: An Alternative to Implied Dedication, 18 UCLA L. REv. 795 (1971); Note, This Land Is My Land: The Doctrine of Implied Dedication and Its Application to California Beaches, 44 S. CAL. L. Rev. 1092 (1971).

${ }^{18}$ Courts in Florida, Hawaii, and Oregon have adopted this approach. See City of Daytona Beach, 294 So. 2d 73 (Fla.); County of Hawaii v. Sotomura, 55 Hawaii 176, 517 P.2d 57 (1973), cert. denied, 419 U.S. 872 (1974); In re Ashford, 50 Hawaii 314, 440 P.2d 76 (1968); Thornton, 462 P.2d 671 (Or.).

${ }^{17}$ See, e.g., Degnan, Public Rights in Ocean Beaches: A Theory of Prescription, 24 
idea in particular has spawned an enormous number of cases and articles, ${ }^{18}$ some urging extension of a public trust to a much wider range of property where public access or control should be vindicated. ${ }^{19}$ But there have also been several very sharp critiques of these cases and articles, and of the expansive doctrines of public control they propound. Some critics deny the underlying public trust and dedicatory theories, and deplore what they see as an unjust and disruptive destruction of private property rights. ${ }^{20}$ They argue that if the public wants or needs these waterfront lands so much, it should have to purchase them from the private owners. ${ }^{21}$ Moreover, they warn of the consequences of these uncompensated and unpredictable transfers of property rights: frustrated private owners may overreact in trying to protect their property from any implication of "dedication" by installing guard dogs or blowing up access paths to the beach. ${ }^{22}$

More generally, these critics reiterate the basic arguments in favor of private ownership: uncertainty about property rights in-

Syracuse L. REv. 935, 960-62, 965 (1973) (beach particularly suited to public prescriptive rights and public use); Stevens, The Public Trust: $A$ Sovereign's Ancient Prerogative Becomes the People's Environmental Right, 14 U.C.D. L. REv. 195, 221-23 (1980) (recreation a proper trust purpose); Note, Public Access to Beaches, 22 Sran. L. Rev. 564, 580-81 (1970) (dedication appropriate for public needs, citing Gion and Thornton).

1s For a sampling of this literature, see The Public Trust Doctrine in Natural Resources Law and Management: A Symposium, 14 U.C.D. L. REv. 181 (1980). Unquestionably the most important article was Sax, The Public Trust Doctrine in Natural Resource Law: Effective Judicial Intervention, $68 \mathrm{MrcH}$. L. REv. 471 (1970), which initiated the continuing avalanche of scholarly and judicial commentary elaborating on-or disputing-the argument that certain lands ought to be public. See Lazarus, Changing Conceptions of Property and Sovereignty in Natural Resources: Questioning the Public Trust Doctrine, 71 Iowa L. REv. 631, 643-44 nn.75-76 (1986) (listing many articles on public trust following Sax); id. at $644 \mathrm{n} .77$ (listing many of the approximately 100 cases in half the states concerning public trust doctrine).

10 See, e.g., United Plainsmen Ass'n v. North Dakota State Water Conservation Comm'n, 247 N.W.2d 457, 461-64 (N.D. 1976) (water subject to public trust, citing inter alia Sax, supra note 18); Payne v. Kassab, 11 Pa. Commw. 14, 312 A.2d 86 (1973), aff'd, 14 Pa. Commw. 491, 323 A.2d 407 (1974), aff'd, 468 Pa. 226, 361 A.2d 263 (1976) (Pennsylvania Constitution places broad range of resources in public trust); Johnson, Public Trust Protection for Stream Flows and Lake Levels, 14 U.C.D. L. Rev. 233 (1980); Sax, Liberating the Public Trust Doctrine from its Historical Shackles, 14 U.C.D. L. REv. 185, 188-89 (1980) (trust doctrine prevents destabilization of public expectations and should extend to renewable resource management generally); Note, Protecting the Public Interest in Art, 91 YaLE L.J. 121 (1981) (arguing that artworks should be subject to a public trust).

${ }^{20}$ See, e.g., Note, Assault on the Beaches: "Taking" Public Recreational Rights to Private Property, 60 B.U.L. Rev. 933 (1980); Note, The Common Law Doctrine of Implied Dedication and Its Effect on the California Coastline Property Owner: Gion v. City of Santa Cruz, 4 Loy. L.A.L. REv. 438 (1971); Note, supra note 15.

21 See, e.g., Note, supra note 15, at 1120-25 (arguing for inverse condemnation).

22 Id. at 1096. 
vites conflicts and squanders resources. The public access cases turn the waterfront into a "commons," where no one has any incentive to purchase the property, invest in it, or care for it, but only to consume as much as possible-all of which leads to deterioration and waste. ${ }^{23}$ Indeed one author, though not entirely unsympathetic to the new cases, sees them as repudiating the view that the common law is efficient: these cases, he asserts, reverse common law doctrines that were relatively efficient while reasserting inefficient common law doctrines. ${ }^{24}$

It is no wonder that these new cases and doctrines expanding public waterfront access are controversial, given their impact on what were thought to be private entitlements. But the question whether these expanded doctrines "take" property without compensation, although exceedingly important to private owners, is in principle perhaps not the most radical issue about these cases. Their rhetoric suggests that no nonconsensual transfer has occurred; in theory, the owner gave or granted his property to the public, or only owned it subject to public rights. Even though this rhetoric sounds implausible, the cases at least pay lip service to the principle that private property may not be taken without compensation. ${ }^{25}$

The more radical feature of these cases is precisely their seeming defiance of classical economic thinking and the common law doctrines so markedly mirroring that theory: they show a preference for public access, superior to the right to exclude that is the supposed hallmark of private property. Such theories are singular exceptions to the standard doctrines of property law. Most property is not impressed with a "public trust" allowing access; why should the beaches be? It begs the question to say that the new cases merely extrapolate from older doctrine about navigable wa-

2s Roberts, Beaches: The Efficiency of the Common Law and Other Fairy Tales, 28 UCLA L. Rev. 169, 177-80 (1980); Comment, supra note 15, at 803. On the commons problem, see the classic work by Hardin, supra note 7.

34 Roberts, supra note 23 , at $175-80$. For the argument that the common law is efficient, see Rubin, Why Is the Common Law Efficient?, 6 J. Legal Stud. 51 (1977); Priest, The Common Law Process and the Selection of Efficient Rules, 6 J. LEGaL Stud. 65 (1977).

${ }^{26}$ There is a striking parallel between these doctrines and some justifications for noncompensation in 19th-century eminent domain cases. One well-known Pennsylvania case echoed the "public trust" doctrine in holding that the original proprietary grant had "reserved" a right to place roads over property, and that owners bought subject to such reservations. See M'Clenachan v. Curwin, 3 Yeates 362, 6 Binn. 509 (Pa. 1802). One might see such a doctrine as a serious assault on property rights, see, e.g., Morton Horwitz, ThE Transpormation of American LaW 63-65 (1977), but in a sense it is an almost pathetic effort to preserve the illusion that nothing is being taken. 
terways: why did the old cases hold submerged lands subject to such a trust? By the same token, no amount of general public usage will subject most property to divestment, either by "implied dedication" or by analogy to adverse possession. ${ }^{26}$ Again, to find analogies in older doctrine about roadways is only to push the question one step back. As to custom, the same questions apply. Until the modern beach cases, "custom" had almost no authority in American law. ${ }^{27}$ Can there possibly be a link between American waterfront recreation and the rights of eighteenth-century British villagers to dig out turf and hold maypole dances on the lord of the manor's lands?

Why, in short, is any property inherently or even presumptively withdrawn from exclusive private appropriation? What characteristics of the property require it to be open to the public at large, and exempt from the classical economic presumption favoring exclusive control?

Perhaps these doctrines are indeed easily explicable through classical economic thought, and can be subsumed under the wellrecognized exceptions to the general principle favoring private and exclusive property rights: "plenteous" goods and "public goods." The first class of exception concerns things that are either so plentiful or so unbounded that it is not worth the effort to create a system of resource management for them, or-stated differently-things for which the difficulty of privatization outweighs the gains in careful resource management. ${ }^{28}$ Thus the oceans and

26 See, e.g., Starr v. People, 17 Colo. 458, 30 P. 64 (1892) (general public use of a lot, as opposed to a particular path, does not establish implied dedication); State ex rel. Shorett v. Blue Ridge Club, 22 Wash. 2d 487, 495-96, 156 P.2d 667, 671 (1945) (owner had no notice of adverse use and is "not required to adopt a dog-in-the-manger attitude in order to protect his . . . property"). On the other hand, a governmental body may acquire property by adverse possession; this highlights the distinction between a corporately organized governmental "public" and the unorganized public-at-large. See infra text accompanying notes 31-40. For recent examples of governmental adverse possession, see, for example, Roche v. Town of Fairfield, 186 Conn. 490, 498-500, 442 A.2d 911, 916 (1982) (distinguishing governmental adverse possession from that of unorganized public at large); see also State ex rel. A.A.A. Invs. v. City of Columbus, 17 Ohio St. 3d 151, 152-53, 478 N.E.2d 773, 775 (1985) (citing cases).

${ }^{27}$ See, e.g., Graham v. Walker, 78 Conn. 130, 133, 61 A. 98, 99 (1905) (customary rights to land do not apply in United States); see also 21 MinN. L. Rev. 107 (1936) (New Hampshire is the only jurisdiction allowing public easements by custom). For a review of the status of custom in American law as of 1935, see Gillies v. Orienta Beach Club, 159 Misc. 675, 289 N.Y.S. 733 (Sup. Ct. 1935), aff'd, 248 A.D. 623, 288 N.Y.S. 136 (1936) (per curiam).

${ }^{28}$ Blackstone recognized this exception in the very phrase that he spoke of "that wise and orderly maxim" assigning an owner to everything capable of ownership; things not capable of ownership were designated as the property of the sovereign. $2 \mathrm{~W}$. BLACKsTONE, supra note 1, at ${ }^{* 14-15}$. More recently, in Anderson \& Hill, The Evolution of Property Rights: A 
air (it used to be said) are at once so plentiful and so difficult to reduce to property that they are left open to the public at large. ${ }^{2 \theta}$ The "plenitude" or "boundlessness" exceptions, however, fail to explain the "publicness" of those properties that our traditional doctrines most strongly deemed public property. Roadways, waterways, and submerged lands-not to speak of open squares, which have also sometimes been presumed public-are hardly so copious or so unbounded that they are incapable of privatization. Riverbeds and shorelands can be staked out, roadways can be obstructed, waterways diverted, squares plowed up; in short, they can easily be "reduced to possession" in the classic common law manner of creating proprietary rights out of a "commons." 30 Thus the "public" character of such lands, or even a public easement over them, must have some basis other than our incapacity to reduce them to private possession.

The second exception to the general rule favoring private property may be of more assistance. Since the mid-nineteenth century, economists have told us that there exist predictable instances

Study of the American West, 18 J.L. \& Econ. 163 (1975), have traced the progress of a number of resources in the American West from a "commons" to a system of property rights, arguing that this occurs as the value of a private property regime comes to outweigh the costs of its administration. For a similar account, tracing the increasing formality in land title registration in colonial New England, see Konig, Community Custom and the Common Law: Social Change and the Development of Land Law in Seventeenth-Century Massachusetts, 18 AM. J. LEGAL Hisr. 137, 148-53 (1974); see also Yandle, supra note 6, at 5 (costs of allocating property rights in natural resources may exceed losses arising from commons overuse).

${ }^{29}$ See, e.g., 2 Hugo Grotius, De Jure Belli ac Pacis 190 (Kelsey trans. 1925) (air and oceans too plentiful and unbounded to reduce to private property). The same used to be said of running water, though the experience of the American West has shown this not to be the case, in effect proving the rule. Running waters were privatized when the gains from careful resource management outweighed the costs of an administrative system for private rights. See Anderson \& Hill, supra note 28, at 177 (water reduced to property). To a degree even the air has become privatized, insofar as pollution rights are granted (and even bought and sold) by permit. See, e.g., Stewart, Economics, Environment, and the Limits of Legal Control, 9 HARv. ENVTL. L. REv. 1, 13-14 (1985) (EPA's "bubble system" contemplates trade of property-like rights of air pollution under Clean Air Act).

so Indeed, much of the case law on these matters has arisen because some owner has succeeded in staking out some allegedly "public" area, and in excluding others from it. See, e.g., Martin v. Waddell, 41 U.S. 366 (1842) (rejecting private proprietary claims to submerged oyster beds); Attorney Gen. v. Woods, 108 Mass. 436 (1871) (suit to remove mill dam across tidal creek as impairment of public property); Corvallis Sand \& Gravel Co. v. State, 250 Or. 319, 439 P.2d 575 (1968) (removal of sand and gravel from streambed established no private rights in public stream, so private party ejected); Carson v. Blazer, 2 Binn. 475 ( $\mathrm{Pa} .1810)$ (excavation of a shad pond did not establish property right to fishing in center of navigable river). For the meaning of "possession" in common law doctrines, see Rose, Possession as the Origin of Property, 52 U. CHI. L. REv. 73 (1985); see also Epstein, Possession as the Root of Title, 13 GA. L. REv. 1221, 1229 (1979). 
of "market failure," where Adam Smith's invisible hand fails to guide privately owned resources to their socially optimal uses. These involve "public goods," "natural monopolies," "externalities," and the like. While some of these problems may be solved by collective agreements among the owners of the resources, such agreements are costly and, particularly where a large number of parties must be involved, private collective action is not always possible. Inefficiencies will remain.

Thus a governmental body might be the most useful manager where many persons desire access to or control over a given property, but they are too numerous and their individual stakes too small to express their preferences in market transactions; governmental ownership could broker those preferences. ${ }^{31}$ Similarly, a government might be a superior manager (or regulator) of a property whose use involves economies of scale-the railways, bridges, or grain elevators whose monopoly position classically justified governmental ownership or control. ${ }^{32}$ Or a government might be a superior manager of those "collective goods" like the broadcast spectrum, wherein some management structure is required to make individual users take account of other users' interests. ${ }^{33}$ In a sense, we rely on governmental management of our preeminent system of resource management-private property-and we might view the entire private property regime as a "public property" owned and managed by governmental bodies. ${ }^{34}$

Conventional wisdom instructs that in such cases, the most productive solution would be for government to assume some or all of the rights of ownership and control over the property, and to use its powers to correct the market's misallocation. This conventional conclusion is subject to four conventional caveats: the state must be able correctly to identify instances of market failure; it

3t See, e.g., Stroup \& Baden, Externality, Property Rights, and the Management of Our National Forests, 16 J.L. \& EcoN. 303, 306-09 (1973) (summarizing market failure rationales for governmental management of national forests); cf. Sagoff, Economic Theory and Environmental Law, 79 Mich. L. REv. 1393, 1402-08 (1981) (difficulty of measuring aesthetic or normative preferences; incommensurability of these diffuse preferences with normal market preferences).

${ }^{32}$ See Adams, Relation of the State to Industrial Action, in Two Essays By HenRY CARTER ADAMS 57, 109-14 (Dorfman ed. 1954) (industries with increasing returns are natural monopolies, justifying either public ownership or regulation); Hadley, Legal Theories of Price Regulation, 1 YaLE REv. 56, 60 (1892).

ss See, e.g., Wiel, supra note 9, at 429 .

34 See Comments of James Krier, American Association of Law Schools, Annual Meeting, Washington, D.C., Session on Property (Jan. 1985) (audio tape) (private property regime is a collective good). 
must be clever enough to exercise its powers so as to reduce the inefficiency; it must avoid errors or political temptations to exercise its powers in ways that create new inefficiencies; and the costs of effective state intervention must not exceed the increase in production it brings about.

This standard paradigm of neoclassical economics and modern microeconomic theory recognizes only two property regimes: either ownership is vested in private parties or it resides with an organized state. The usual economic approach to property law suggests that productive efficiency will be enhanced when private property is the norm, but government intervenes in recognized instances of market failure.

Thus in the conventional lore, markets are based on private rights or, when markets fail, property may be governmentally managed in the interests of aggregate efficiency. Yet these two options do not logically exhaust all the possible solutions. Neither can they adequately describe all that one finds in the recorded history of property in the Anglo-American universe. In particular, there lies outside purely private property and government-controlled "public property" a distinct class of "inherently public property" which is fully controlled by neither government nor private agents. Since the Middle Ages this category of "inherently public property" has provided each member of some "public" with a bundle of rights, neither entirely alienable by state or other collective action, nor necessarily "managed" in any explicitly organized manner. Aside from individual private property, the nineteenth-century common law of property in both Britain and America, with surprising consistency, recognized two distinguishable types of public property. One of these was property "owned" and actively managed by a governmental body. The other, however, was property collectively "owned" and "managed" by society at large, with claims independent of and indeed superior to the claims of any purported governmental manager. It is this latter type that I call "inherently public property."

Implicit in these older doctrines is the notion that, even if a property should be open to the public, it does not follow that public rights should necessarily vest in an active governmental manager. Despite the well-known problems of unorganized collective access to a resource-the "tragedy of the commons"-equally difficult problems are posed by governmental management: the cost of instituting that management and, perhaps, the temptations of politically motivated redistribution. In some circumstances, then, nineteenth-century common law recognized collective public rights 
as the optimal alternative whether or not those rights were managed governmentally.

Thus our historic doctrines about "inherently public" property in part vested property rights in the "unorganized public" rather than in a governmentally-organized public. ${ }^{35}$ For example, the public sometimes had a right of access to property whether or not a governmental body had intervened. ${ }^{36}$ Moreover, the "trust" language of public property doctrine, in an echo of natural law thinking, suggested that governments had some enforceable duties to preserve the property of the "unorganized" public. ${ }^{37}$ Indeed the "trust" language suggested that even governmental ownership of certain property is only a "qualified," "legal" ownership, for the "use" of public at large, which in classic trust language is the beneficial owner. ${ }^{38}$

Yet property in such an unorganized public would amount to an unlimited commons, which seems not to be property at all, but only a mass of passive "things" awaiting reduction to private property through the rule of capture or, worse yet, their squandering in the usual "tragedy of the commons." Nevertheless, strange though it may seem, precisely this unorganized version of the "public" is strongly suggested in some of the earlier public property doctrine-and in some modern law as well. ${ }^{38}$

3s See infra text accompanying notes 84-187.

se See infra text accompanying notes 91-105.

${ }^{37}$ See infra text accompanying notes 116-33. For the phrase "unorganized public," see Phillips v. Stamford, 81 Conn. 408, 412, 71 A. 361, 363 (1908).

ss See, e.g., Rung v. Shoneberger, 2 Watts $23,25-26$ ( $\mathrm{Pa} .1833$ ) (government's ownership of square is "qualified"; city is "trustee" for the public's "use"). The word "use" itself, of course, is a traditional way to designate beneficial ownership in property held in trust.

39 Joseph Sax, a chief modern proponent of "public trust" doctrine, has disputed the property basis of the doctrine. See Sax, supra note 18, at 478-84. Other writers, however, have argued that Sax's views entail precisely such a vesting of property rights in the general public. See, e.g., Coquillette, supra note 9, at 811-13 (criticizing Sax and arguing that the public may have property rights that restrain legislature from alienating property except in furtherance of "trust" purposes); Juergensmeyer \& Wadley, The Common Lands Concept: A "Commons" Solution to a Common Environmental Problem, 14 NAT. Resources J. 361, 377-79 (1974) (arguing that Sax's position entails a property right in the public, despite his disclaimer); see also Note, State Citizen Rights Respecting Greatwater Resource Allocation: From Rome to New Jersey, 25 RUTGERS L. REv. 571, 697-98 (1971) (criticizing Sax's reasoning on this point). The unorganized public therefore may have a cause of action against governmental "divestments." See Jaffee, The Public Trust Doctrine is Alive and Kicking in New Jersey Tidal-waters, 14 NAT. Resources J. 309, 318, 334-35 (1974) (tidewater resources are property of N.J. citizens, beyond legislative authority to alienate); Stevens, supra note 17, at 210 (19th-century public trust doctrine protected public against legislature); Note, supra, at 696-701 (in certain situations, the citizens' interest in greatwaters is separate from, and stronger than, the state's police power). For a historical treatment of the view of certain lands as inalienable even by the legislature, see Deveney, supra note 9, at 51- 
The modern doctrines are singularly unhelpful in explaining why and under what circumstances property rights might appear to vest in the public at large, the "unorganized public." Despite its popularity, the modern public trust doctrine is notoriously vague as to its own subject matter; cases and academic commentaries normally fall back on the generality that the content of the public trust is "flexible" in response to "changing public needs." And the recent judicial expansions of public access, like the academic literature, often simply refer us back to traditional doctrines.

Hence I turn to these older doctrines for enlightenment, and in the remainder of this article $I$ investigate the problem of inherently public property through a closer examination of older doctrines whereby the public acquired rights to use property. In large part I use cases from the nineteenth century, but will occasionally stray as far forward as the 1920s. I make no claim to historical completeness, and where appropriate I use modern law-andeconomics explanations; but I hope, through an admittedly impressionistic sampling, to capture the flavor of the older views about why some properties should be exempt from the normal realm of exclusive private control.

The doctrines of "public trust," "prescription," and "custom" have traditionally supported public claims of access to roads, waterways, and some other locations. Prescriptive doctrines in roadways, and "trust" doctrines in waterways, I shall call the "strong" doctrines, since they were so much more prevalent in the United States than the "weak" doctrine of custom. Although custom was viewed as the weakest of the three doctrines, however, I argue that it provides powerful insights into the nature of "inherently public property" as a whole, particularly such questions as who was "the public," and why public access to certain property was seen as par-

54. For some recent cases depicting the public trust doctrine as a restraint on legislative acts, see City of Berkeley v. Superior Court, 26 Cal. 3d 515, 606 P.2d 362, 162 Cal. Rptr. 327, cert. denied, 449 U.S. 840 (1980); Paepcke v. Public Bldg. Comm'n, 46 IIl. 2d 330, 263 N.E.2d 11 (1970) (citing Sax but deciding on a property basis); Boston Waterfront Dev. Corp. v. Commonwealth, 378 Mass. 629, 393 N.E.2d 356 (1979); Opinion of Justices to the Senate, 383 Mass. 895, 424 N.E.2d 1092 (1981); Matthews v. Bay Head Improvement Ass'n, 95 N.J. 306, 471 A.2d 355, cert. denied, 105 S. Ct. 93 (1984).

to See, e.g., Sax, supra note 18, at 556-57; Tarlock, Book Review, 47 IND. L.J. 406, 413 (1972); Wilkinson, The Public Trust Doctrine in Public Land Law, 14 U.C.D. L. REv. 269, 315 (1980); Note, Beach Access, supra note 14, at 1071. The case law also reflects this vague formulation. See, e.g., Matthews, 471 A.2d at 365 (public trust is "flexible"). On the confusing character of public trust doctrine, particularly with respect to public lands, see Jawetz, The Public Trust Totem in Public Land Law: Ineffective-and Undesirable-Judicial Intervention, 10 EcoLoGy L.Q. 455, 467-68 (1982). 
ticularly valuable.

As will appear, service to commerce was a central factor in defining as "public" such properties as roads and waterways. Used in commerce, some property had qualities akin to infinite "returns to scale." Thus here, the commons was not tragic, but comedic, in the classical sense of a story with a happy outcome. And customary doctrines suggest that commerce might be thought a "comedy of the commons" not only because it may infinitely expand our wealth, but also, at least in part, because it has been thought to enhance the sociability of the members of an otherwise atomized society.

This sets the stage for a return to the beach. I conclude by suggesting that in the twentieth century there may be other versions of the comedy of the commons, and other practices that share with commerce the power to enhance our sociability. We might even think that properties devoted to such noncommercial uses as recreation or speech could achieve their highest value when they are accessible to the public at large.

\section{The "Publicness" of the Roads and Waterways: A Brief History OF THE "STRONG" Doctrines}

A. Prescription-Herein Chiefly of Roads, Highways, and Streets

If classical economic theory normally preferred individual ownership of property to limitless access, ${ }^{41}$ the traditional rules for public acquisition of streets and roads systematically overlooked that preference. Indeed, public acquisition of roadways by long usage seems a particularly striking illustration of the imperviousness of practice to theory: the doctrines by which the public acquired roads over private property, without purchase even through eminent domain, flourished side by side with the popularization of classical economics and burgeoning of privately owned commerce and industry. ${ }^{42}$

4 See supra text accompanying notes 1-8.

42 The flourishing of public property doctrines was undoubtedly an aspect of the broader development of "public rights" doctrines documented by Harry Scheiber, supra note 10 , at 221-27, 233-49. Aside from the prescriptive doctrines discussed here, officially sanctioned acquisitions of roadway property could also quite drastically affect seemingly private rights. See, e.g., M'Clenachan v. Curwin, 3 Yeates 362, 6 Binn. 509 (Pa. 1802) (no compensation for a roadway taken for a turnpike); see also M. HoRwitz, supra note 25, at 70-74 (doctrine altered to further public works); Scheiber, The Road to Munn: Eminent Domain and the Concept of Public Purpose in the State Courts, in 5 Persp. AM. Hist. 329, 362-65 (1971) (limited compensation for damage caused by roadways and public improvements generally); cf. Louis Hartz, Economic Policy and Democratic Thought 159-60 
Under theories that I call "prescriptive," a long period of public use was and still is said to deprive a private owner of the right to exclude the public from a traveled way. The reasoning is either that such usage implies that the private owner "dedicated" the right of way to the public, or that usage allows the public to take a property interest by analogy to adverse possession (a fictionalized "lost grant"), or some combination of the two. These doctrines have traditionally been narrow and quite specific, applying to roadways but not to other property. ${ }^{43}$

Though I call both these doctrines "prescriptive," since both are based on usage over time, "prescription" technically referred only to acquisitions based on adverse use rather than dedication.4 In fact, "implied dedication" was the more common doctrine. ${ }^{45}$ The legal development of this doctrine clearly accompanied the march of commerce and industry; Joseph Angell and Thomas Durfee, in their famous 1857 treatise on highways, stated that the first recorded case of a landowner's "implied dedication" of a road to the public occurred in England in 1732, and the doctrine had come into full flower by the mid-nineteenth century. ${ }^{46}$

In theory, when a landowner left his land open to public use, a court could infer that he intended to give the land-or technically, an easement-to the public; and as with any completed gift, he and his successors could not later repudiate this "dedication." But this gift analogy raised an interesting problem. For a time, it was said that no one could make a gift to the public, because "the

(1948) (tendency toward high compensation in eminent domain); Freyer, Reassessing the Impact of Eminent Domain in Early American Economic Development, 1981 WIs. L. REv. 1263 (challenging thesis of undercompensation).

43 See, e.g., Starr v. People, 17 Colo. 458, 460, 30 P. 64, 65 (1892) (general public's use of property does not establish claim in absence of specific pathway).

4 See, e.g., State v. Kansas City, St. J. \& C.B. Ry., 45 Iowa 139, 142 (1876) (noting unfavorably the general usage of "prescription" rather than "dedication"); Note, Does Public User Give Rise to a Prescriptive Easement or Is It Merely Evidence of Dedication?, 6 TEx. L. REv. 365, 367-78 (1928) (drawing distinctions between doctrines). I refer to both doctrines as "prescriptive" because their proofs have become so close, both resting on public use over a period of time. For an important recent example of the blurring of prescription and adverse use, see Gion, 2 Cal. $3 \mathrm{~d}$ at 43-44; for 19th-century examples, see infra text accompanying notes 57-62.

45 J. Angell \& T. Durfee, A Treatise on the Law of Highways § 131 (1857).

48 Id. $\$ 133$.

47 Id. $\S \S 135,156$ ("dedicating" owner precluded from reasserting exclusive right to property). Strictly speaking, the public acquires an easement, with the owner retaining the underlying fee interest. See, e.g., President of Cincinnati v. Lessee of White, 31 U.S. (6 Pet.) 431, 437 (1832); McRose v. Bottyer, 81 Cal. 122, 126, 22 P. 393, 394-95 (1889) (dedicated road is easement or right of way). 
public" was an insufficiently specific donee. ${ }^{48}$ This amounted to saying that the general public was not competent to act as a property owner: property had to be managed by particular, identifiable persons. By the later nineteenth century American courts had found a way around this doctrinal difficulty, although their solution was something of a sidestep. Instead of addressing the issue of the public's competence to receive property, the courts focused on the "donor's" acts and asserted that however weak the public's claim to ownership might be, the landowner's was still weaker: the landowner's own acts estopped him from claiming that those to whom he had "given" a street were incompetent to receive it. ${ }^{49}$

The doctrine of implied dedication also raised a second muchdiscussed problem: "dedication" required a clear manifestation of the owner's intent to give over his property to public use. ${ }^{50}$ Sometimes the owner's intent indeed seemed obvious, as when he platted a subdivision and indicated on a map, "public street." ${ }^{61}$ But sometimes intent was much less clear, since intent "need not always actually exist in [the] mind of the land-owner," but was simply a matter of appearances. ${ }^{52}$ Some courts even said that the owner's "dedication" could be inferred from public use alone, if it went on long enough-commonly twenty years. ${ }^{53}$ But lesser periods would sometimes do, if the circumstances warranted. ${ }^{\text {s4 }}$

These hagglings about length of time focused less on the landowner's intent than on the public's acts, and thus suggested an analysis based on adverse use-_prescription" in the technical

48 J. ANgell \& T. DuRfEe, supra note $45, \S 135$. The same problem dogged charitable contributions for a time. See id.; President of Cincinnati, 31 U.S. (6 Pet.) at 435 . See also Bolger v. Foss, 65 Cal. 250, 251, 3 P. 871, 871-72 (1884), discussed infra at text accompanying note 56 , which held that the public could take by implied dedication but not by grant.

4. See, e.g., Smith v. City of San Luis Obispo, 95 Cal. 463, 470, 30 P. 591, 593 (1892) (owner estopped from taking back what own acts suggest has been dedicated); Wood v. Hurd, 34 N.J.L. 87 (1869) (dedication rests on estoppel); see also B. ElLIoTT \& W. ElLIOTT, A Treatise on the Law of Roads and StreEts, $\$ 132$, at $142-43$ (2d ed. 1900).

so J. ANGELL \& T. DURFEE, supra note $45, \S 147$ (intent to dedicate must be "unequivocal"); see also Kyle v. Town of Logan, 87 III. 64, 66-67 (1877) (asserted dedication rejected for inconclusive intent).

s1 See B. Elliott \& W. Elliotr, supra note 49 , § 118, at 128 (plat as evidence of dedication); see also President of Cincinnati, 31 U.S. (6 Pet.) at 440-41 (intent to dedicate park inferred from plan).

32 B. Elliotr \& W. Elliotr, supra note 49, § 126, at 137.

ss See, e.g., Odiorne v. Wade, 22 Mass. (5 Pick.) 421 (1828); J. Angell \& T. DurfeE, supra note 45, § 143; B. ElliotT \& W. ElliotT, supra note 49, § 159, at 170; see also Devenpeck v. Lambert, 44 Barb. 596 (N.Y. Sup. Ct. 1865) (interpreting statute providing that 20 years of unobstructed public use gives rise to public ownership).

s4 J. ANGell \& T. DurfeE, supra note 45, §§ 144-45; B. Elliotr \& W. ElliotT, supra note $49, \S \S 160-61$, at 171-74. 
sense. ${ }^{.55}$ Some courts, however, particularly earlier in the century, rejected adverse use analysis even though they would permit implied dedication. As late as 1884, the California Supreme Court shied away from the adverse use analysis, for reasons again raising the interesting issue of the public's ability to own property: adverse possession technically was based on the fiction of a "lost grant," and the general public was incapable of receiving a grant, even though it might receive property by "dedication."

The distinction between dedication and a "lost grant" seemed hypertechnical, and some courts disregarded it. ${ }^{57}$ Insofar as the distinction made practical sense, the reasoning was as follows: A so-called "lost grant" was proved by long usage inconsistent with the claims of the true owner. ${ }^{58}$ When the adverse use was simply that of an individual, the rightful owner might prevent it by bringing an action to oust the interloper; but for use by the public at large, he had no distinct defendant to sue. ${ }^{59}$ Moreover, it is burdensome on an owner to suppose that prescriptive use by perhaps a few people can translate into a claim in the public at large ${ }^{60}$ As a result, the general public was (and still is) usually held to be unable to claim land by analogy to adverse possession: public trespass can hardly imply an owner's "grant," because the owner cannot rebut the "grant," which may turn out to be considerably larger than any use of which he should have been aware. "Dedication," on the other hand, looked to the owner's own manifestations of intent, and it was his own act (such as platting land for public use) that suggested a gift; he could have rebutted this suggestion by acting differently.

By 1900, however, hardly anyone cared about the difference. In California, the Supreme Court distinguished away its earlier reservations about adverse use, and blurred adverse use and dedication theories in Schwerdtle $v$. County of Placer, ${ }^{61}$ presaging the

SB This appearance is heightened by the use of the 20-year period of public use as evidence of "dedication"; this was a common period for adverse possession. See C. HAAR \& L. Liebman, Property and Law 80 (2d ed. 1985).

B8 Bolger v. Foss, 65 Cal. 250, 251, 3 P. 871, 871-72 (1884); see also Note, supra note 44, at 375-76 (criticizing doctrine of adverse use, preferring dedication).

${ }^{s 7} \mathrm{See}$, e.g., Wood v. Hurd, 34 N.J.L. 87, 92 (1869) (designation of prescription, adverse possession, or dedication is "a mere difference in name").

ss See, e.g., Cherry v. Stein, II Md. 1, 22 (1858) (unusual for owner to submit to encroachment over long time; if encroachment happens, is presumed to be by right).

${ }^{89}$ See the discussion in State ex rel. Thornton v. Hay, 254 Or. 584, 593-94, 462 P.2d 671,676 (1969).

0 See Livingston, supra note 15 , at 690 , and authorities cited therein.

o1 $108 \mathrm{Cal}$. 589, 592, 41 P. 448, 449 (1895) (dedication presumed from adverse use); see 
similar blend of theories in the modern beach acquisition cases. ${ }^{62}$ At present, courts routinely use adverse use analyses in road dedication cases, or some unspecified mixture of dedication and adverse use theories, ${ }^{63}$ and they ignore the difficulties that an owner might have in bringing a trespass action against the public at large.

Thus, by the end of the century, the prescriptive doctrines for roadways, taken together, acted as a double-edged sword against the landowner. If he did nothing to halt the public's use, he might be regarded as dedicating the roadway to the public. If he attempted to halt that use and failed, he could lose his rights under a theory of adverse user. In short, the landowner could do very little to prevent the implication of public ownership of a roadway, aside from making the passageway physically impassable. ${ }^{64}$ This is not to say that public claims always defeated landowners; sometimes the landowners won. ${ }^{65}$ But the prescriptive doctrines generated no real tests for the character of the use that could establish public acquisition of a road. And this in turn suggests the extraordinary strength of the view that roads should be public property, whatever the contradictions that may lurk between the concepts of "public" and "property."

\section{B. Public Trust-Tidal and Submerged Lands and the Water- ways Over Them}

If roadways enjoyed a strong presumption of "publicness" in nineteenth-century doctrine, waterways and submerged lands enjoyed an even stronger one. The idea of a "public trust," so prevalent in current land use literature, originated in doctrines relating to ownership of lands washed by the tides and lying beneath navi-

also State v. Kansas City, St. J. \& C.B. Ry., 45 Iowa 139, 142 (1876) (reluctantly accepting terminology based on adverse use).

2 See Gion, 2 Cal. 3d at 43-44 (mix of adverse possession and dedication theories).

os See, e.g., Stevenson v. Meyer, 10 Ill. 2d 335, 338, 139 N.E.2d 740, 742-43 (1957) (dedication based on public use that is open, notorious, with claim of right); Bain v. Fry, 352 Mich. 299, 305, 89 N.W.2d 485, 489 (1958) (similar analysis); see also Tolliver v. Louisville \& N.R.R., $226 \mathrm{Ky} .132,135,10$ S.W.2d 623, 625 (1928) (no distinction drawn between dedication and adverse use theories); State ex rel. Game, Forestation \& Parks Comm'n v. Hull, 168 Neb. 805, 811-12, 97 N.W.2d 535, 541 (1959) (adverse use and prescriptive theories called "substantially identical"); Note, Dedication of Land in California, 53 CaLIF. L. REv. 559, 562 n.23 (1965) (tests for dedication and prescription are substantially identical in California).

64 For a modern version, see Comment, supra note 15, at 802; 1 RoBert ClaRK, WATERS AND WATER RIGHTS $\S 38: 2$ (B) (1967 \& Supp. 1978) (noting a similar problem in the dedication of water passage).

As See infra text accompanying notes $85-90,191-95,245-53$. 
gable waters. ${ }^{68}$ American legal scholars have long stated that despite the general presumption of exclusive individual ownership of land, submerged and tidal lands and the waters flowing over them were owned first by the King of England-more or less a metaphor for "presumptively open to the public" tion by the American states. ${ }^{68}$ These lands and their waters were held in trust for the public's rights of navigation and fishing (and perhaps other uses); ${ }^{69}$ and even if alienated, these lands would continue to be impressed with the public "trust." This trust is in the nature of an inalienable easement, assuring public access.

Although American and English jurists confidently espoused the sovereign's "trust" ownership of the tidelands as if it dated at least from Magna Carta, ${ }^{70}$ strong evidence exists that the theory originated much more recently. ${ }^{71} \mathrm{~A}$ sixteenth-century royalist polemicist was apparently the first to elaborate the idea that tidal lands prima facie belonged to the crown, even though at the time, English submerged and tidal lands had long been held by private owners. ${ }^{72}$ After a number of years of general disfavor, ${ }^{73}$ the theory

${ }^{66}$ See Deveney, supra note 9, at 14; Sax, supra note 18, at 475; Note, Tidal Areas, supra note 14 , at $763-64$.

${ }^{67}$ See, e.g., Martin v. Waddell, 41 U.S. (16 Pet.) 367, 412 (1842) (public has trust rights of navigation and fishing over submerged lands); see also infra note 68.

${ }^{68}$ See Martin, 41 U.S. (16 Pet.) at 416 (ownership of New Jersey submerged lands was part of governmental authority given to colonial proprietors, then devolving to the state of New Jersey). According to Angell, colonial proprietors and later the American states succeeded to the royal "proprietorship" of submerged lands. J. ANGELL, supra note 6, at 38-39, 50-51. Angell, no doubt a good republican, was at pains to dispute the notion that royal ownership meant royal disposability; this ownership, he argued, was only a trusteeship for the public at large, such that the people's rights in the foreshore were not dependent on any royal grant and could not be alienated by the king. Id. at 17-18, 20-21 (citing Bracton and Blackstone). Parliament, on the other hand, could dispose of trust lands, as could the American legislatures, who represented the public. Id. at 106-07. Angell thus thought that the state governments had greater rights than the king, since these governments represented the sovereign completely, unlike the king, whose authority was shared with Parliament. Id.

69 The main additional contenders are now recreation and environmental preservation. See, e.g., Stevens, supra note 17, at 222. For the development of recreation as a "trust" purpose, see infra text accompanying notes 210-29.

${ }^{70}$ See, e.g., Martin v. Waddell, 41 U.S. (16 Pet.) 367, 410 (1842) (citing tidelands trusteeship back to the Magna Carta).

${ }^{71}$ MacGrady, supra note 9, at 559 (argues that the theory of royal tidelands ownership is relatively recent, beginning with tract by Tudor polemicist Digges); cf. PETER RIESENBERG, Inalienability of Sovereignty in Medieval. Political Thought 37-47 (1956) (tracing the medieval concept that royal and other governing authorities could not alienate their office, sometimes including the property that maintained that office).

72 Deveney, supra note 9, at 41-42; MacGrady, supra note 9, at 554, 559; see also Wiel, supra note 9 , at 451 (linking tidelands royal ownership theory to Stuart monarchs' overreaching).

73 Deveney, supra note 9, at 42; MacGrady, supra note 9, at 561-62. 
was restated in Sir Matthew Hale's treatise De Jure Maris. ${ }^{74}$ According to this widely-cited work, tidal lands were "presumed" to belong to the crown in the absence of evidence to the contrary, such as a charter or a showing of long usage suggesting a "lost grant." In American law, the presumption of "sovereign" ownership of submerged lands was soon extended from tidelands to land beneath navigable streams generally. ${ }^{75}$ In addition, what for Hale had been a mere presumption was transformed by American jurists into a brute assertion: not even the king himself could alienate trust property free of its subservience to the people's trust rights. ${ }^{78}$

However historically contingent this idea of a "public trust" might have been, and however sharp the criticism it received both originally and in more recent scholarship, ${ }^{77}$ it has exerted a persistent hold on American law since the early nineteenth century. Public trust doctrine has enjoyed at least three waves of popularity, traceable to particular cases or events. The first American case to apply the phrase to waterways was Arnold v. Mundy ${ }^{78}$ in 1821; despite its very doubtful authority, its "public trust" language re-

74 Matthew Hale, De Jure Maris, reprinted in Stuart Moore, A History of the Foreshore AND the Law Relating Thereto 370, 374 (3d ed. 1888). Hale's book was written in the 1660s but first published in 1786. For the publication history of Hale's treatise, see id. at 317-18. Another source describes Hale's work as "very influential." See I R. CLARK, supra note 64, $\$ 36.3 \mathrm{~A}$. On the importance of Hale's work in 19th-century American jurisprudence, see Scheiber, supra note 42 , at $336,339-44$.

${ }^{75}$ The leading early case is Carson v. Blazer, 2 Binn. $475,483-85(\mathrm{~Pa} .1810)$; see also Barney v. Keokuk, 94 U.S. 324, 338 (1876) (state has property in lands beneath waters navigable in fact). For the admiralty law version of this (extending admiralty jurisdiction to waters navigable in fact), see Propeller Genesee Chief v. Fitzhugh, 53 U.S. (12 How.) 443, 457 (1851). The extension of navigability also affects the reach of the national commerce power. See MacGrady, supra note 9, at 593-94.

76 See, e.g., J. ANGELL, supra note 6, at 21; see also Deveney, supra note 9, at 51-56 (American courts misinterpreted Hale in linking public rights to invented doctrine of inalienable sovereign ownership).

77 For contemporary criticism, see Justice Catron's dissent in Pollard v. Hagan, 44 U.S. (3 How.) 212, 232 (1845) (arguing that the United States owns tidelands and may alienate them like any other owner). See also the very able losing arguments of counsel in Martin v. Waddell, 41 U.S. (16 Pet.) 367, 398, 400-04 (1842) (crown could alienate submerged lands). For modern criticism, see, for example, Deveney, supra note 9, at 54, and MacGrady, supra note 9 , at $549-51$.

${ }^{78} 6$ N.J.L. 1, 71-78 (1821); see also MacGrady, supra note 9, at 590-91 (criticizing Mundy and cases relying on it). In Pollard v. Hagan, 44 U.S. (3 How.) 212 (1845), which established that the states owned the lands beneath navigable waters, dissenting Justice Catron complained that this linkage of state sovereignty to state tidelands ownership was "unheard of" before the period between 1840-44. 44 U.S. (3 How.) at 231 (Catron, J., dissenting). Interestingly, the language of "public trust" was used as early as 1802 in a roadway case. See M'Clenachan v. Curwin, 3 Yeates 362, 367-68, 371 ( $\mathrm{Pa} .1802)$ (percentage of land grants reserved "in trust" for the community for roadways; owner held land "as a trustee for the public"). 
surfaced in the next decades as a foundation for public claims to submerged lands. ${ }^{78}$ A second flurry occurred after the $1892 \mathrm{Su}-$ preme Court decision, Illinois Central Railroad v. Illinois, ${ }^{80}$ as several state cases used it to launch their own expanded versions of the public trust in waterways. ${ }^{81}$ The most recent wave has occurred in the last fifteen years, in the wake of Joseph Sax's article applying public trust doctrine to natural resource law more generally ${ }^{82}$ Since then, the environmental journals have published reams of public trust literature, and several state courts have extended public trust doctrine to new purposes and new types of property. ${ }^{83}$

A particularly striking aspect of this historical pattern is the resonance that public trust doctrine has in our law, despite frailties in its original authority. It is equally striking that "public trust" doctrines in waterways, like the doctrines easing public acquisition of roadways, flourished alongside the popularization of classical economic theory - a theory that generally rejected the notion that the general public could own and manage property.

\section{Who Was the Public? The Uneasy Relationship of "Governmental" and "Unorganized" Publics}

One way to solve the conundrum of "public property" would be to equate the "public" with government. This form of public property would be no more than a variant on private property, wherein a corporately organized body could claim exclusive control over property-investing in it, managing it, exchanging it-just as a private owner would; such a solution would obviate the "commons" problems thought to accompany nonexclusive use. But some nineteenth-century courts rejected this neat solution, and located the public's rights in what other courts perhaps disapprovingly

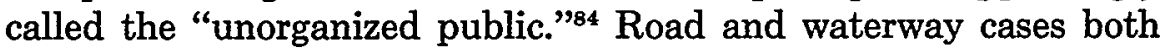

79 MacGrady, supra note 9, at 590-91 (describing 1830s and 1840s use of public trust doctrine in submerged lands, on weak authority of Mundy); see also Selvin, supra note 10, at 1410-12 (litigation over ownership of submerged lands and alluvion). Selvin also notes that through the mid-century and beyond, public trust doctrine was used to dispose of a variety of issues about lands belonging to public bodies, such as California pueblo lands and railroad and non-travel use of publicly owned streets. Id. at 1412-18.

so 146 U.S. 387 (1892); see also infra text accompanying notes 125-29.

s1 See, e.g., Lamprey v. State, 52 Minn. 181, 199-200, 53 N.W. 1139, 1143 (1893) (public trust includes recreation); Diana Shooting Club v. Husting, 156 Wis. 261, 145 N.W. 816 (1914) (same); see also infra text accompanying notes 209-29; Sax, supra note 18, at 509 (discussing post-Illinois Central cases in Wisconsin); infra text accompanying notes 130-33.

${ }^{82}$ Sax, supra note 18.

${ }^{83}$ See authorities cited supra note 18.

s4 For this phrase, see Phillips v. City of Stamford, 81 Conn. 408, 412, 71 A. 361, 363 
clearly showed this tendency-as well as its controversial character.

\section{A. The Roadway "Acceptance" Controversy: Prescription and "Publicness"}

Although prescriptive doctrines clearly became a powerful source for public claims to roadways during the nineteenth century, some private owners nevertheless prevailed. ${ }^{85}$ One common reason was that the public had not "accepted" a dedicated road and thus did not own it. ${ }^{86}$ Just beneath the surface of this "acceptance" issue lay a thinly veiled argument about who counts as the "public."

Among the many cases raising this question was a midnineteenth-century Maine decision, State v. Bradbury, ${ }^{87}$ where a landowner was indicted for building a house on a road alleged to be public. The defendant claimed that the property was his own, and the court agreed. Although there was some evidence of "dedication" of the roadway, the court said, the road would not be regarded as public without further evidence that some organized governmental authorities had "accepted" it. ${ }^{88}$ The Bradbury court gave the classic reasons for insisting on official acceptance. Without it, a landowner could connive to open a roadway wherever he pleased and foist responsibility for its upkeep on local governments, thus evading the requirement that the constituted authorities assent to new duties which would burden the public treasury. ${ }^{89}$

(1908); Guthrie v. Town of New Haven, 31 Conn. 308, 320-21 (1863); Sage v. Mayor of New York, 154 N.Y. 61, 79, 47 N.E. 1096, 1101 (1897).

${ }^{3 s}$ See supra text accompanying notes 64-65.

so For an older case, see, for example, People ex rel. Shurtz v. Commissioners of Highways, 52 Ill. 498, 502 (1869) (public use alone is not complete dedication without governmental assent); State v. Bradbury, $40 \mathrm{Me}$. 154, 158 (1855) (same). For more modern cases, see Bain v. Fry, 352 Mich. 299, 305, 89 N.W.2d 485, 488-89 (1958) (same); Owens v. Elliott, 257 N.C. 250, 254-55, 125 S.E.2d 589, 592 (1962). The "acceptance" requirement may seem inapt where the theory is adverse use rather than implied dedication, but no one seems to care, perhaps because the distinctions between the two theories have blurred. See supra text accompanying notes 61-63. At least one jurisdiction, however, has noticed a difference even while it melds the theories, saying that where the "dedication" is based on adverse use, the public's "acceptance" may be more informal. Huggett v. Moran, 201 Or. 105, 111-12, 266 P.2d 692, 695 (1954).

87 40 Me. 154 (1855).

Bo Bradbury was unusually stringent on "acceptance." Ordinarily acceptance could be established by evidence of county grading or improvements or some similar act. See B. ElLLIOTT \& W. ElLIOTT, supra note 49, $\$ \$ 152-53$, at 160-63. But in Bradbury, even the county surveyor's improvements were insufficient enough, perhaps because it was thought that a lower officer could not bind the county legislative body. See $40 \mathrm{Me}$. at 157 .

so 40 Me. at 157-58; see also Green v. Town of Canaan, 29 Conn. 157, 169-70 (1860) 
A few years after Bradbury, the Supreme Court of Illinois made the same point, adding that such acts by individual landowners could contradict "the wishes of [a local government's] proper officers and and of a great majority of its people," and were especially pernicious in "a [s]tate like ours," where, because of its undeveloped character, roads and bridges caused great expense and high taxes. ${ }^{90}$

The underlying theory of these "official acceptance" cases was thus government by consent. The citizens were presumed to consent to the decisions of their governing officials because they consented to the larger system of government. But it could not be assumed that the citizenry consented to be bound by individual landowners and road users who acted without authority and only in their own behalf, who might well constitute only a minority of the citizenry. These midcentury cases implicitly rejected a more expansive English doctrine of acceptance, ${ }^{91}$ which required no official adoption or acceptance and held that the general public, by using a passageway as a road, made that roadway public. On this doctrine, the public "accepted" by its very use, and there was a strong suggestion that local officials had no choice but to take responsibility. ${ }^{92}$ In America, however, Angell and Durfee suggested that official acceptance was usually necessary in the absence of a statute to the contrary. ${ }^{93}$

But by the end of the century, things had changed. In their 1900 treatise on roads, Byron and William Elliott noted that there continued to be "much diversity of opinion" on the matter" (as indeed is still the case), ${ }^{95}$ but that the "prevailing opinion" was that acceptance could be inferred from long and general use by the public as of right. ${ }^{96}$ This altered doctrine viewed the "accepting"

(Ellsworth, J., dissenting). For a somewhat later example, finding that even 20 years of public use did not vest a roadway in the public without official acceptance, see Johnson v. City of Niagara Falls, 230 N.Y. 77, 129 N.E. 213 (1920).

90 People ex rel. Shurtz v. Commissioners of Highways, 52 Ill. 498, 502 (1869).

${ }^{91}$ Rex v. Leake, 5 B. \& Ald. 469, 482, 110 Eng. Rep. 863, 868 (K.B. 1833).

92 Id. at $482,484,487$.

93 J. ANGEll \& T. DuRfEe, supra note 45, §§ 159-60; cf. Reed v. Northfield, 30 Mass. (13 Pick.) 94, 97-98 (1832) (Shaw, C. J., remarked that if 40 years of public use were insuffcient, some of the oldest and most important highways would not be public roads).

*4 B. ElliotT \& W. ElliotT, supra note 49, § 154, at 163.

${ }^{93}$ Compare, e.g., Bain v. Fry, 352 Mich. 299, 305, 89 N.W.2d 485, 488-89 (1958) (requiring official act to accept road), and Union Transp. Co. v. Sacramento County, 42 Cal. $2 \mathrm{~d}$ 235, 243-44, 267 P.2d 10, 15 (1954) (requiring at least informal acceptance by officials; discussing rule requiring no official act), with Manderschid v. City of Dubuque, 29 lowa 73, 81 (1870) ("no formal acceptance other than public use is necessary").

${ }^{98}$ B. ElliotT \& W. ElliotT, supra note 49, § 163, at 154. 
public as the unorganized public at large, and not necessarily as a public organized into a governmental body. Here too a "consent" theory supported the doctrine: a municipal corporation consists of the inhabitants and not the officers, the latter being mere agents for the former; if the inhabitants by their conduct accept the dedication, this suffices as an act of the principals, and needs no further intervention by the agents. ${ }^{97}$

One difficulty with this theory was its insensitivity to the majority/minority problem stated in earlier cases. Phillips $v$. Town of Stamford ${ }^{98}$ illustrated this: a small number of individuals, walking over a beach access road at irregular times, were held to have "accepted" the road for the larger public. According to the court, even a few members of the "unorganized public" could disclose the public's attitude by their foot traffic. ${ }^{9 \theta}$ Thus even a small number of persons could act for all, at least where those who were "naturally expected" used the land at their pleasure. ${ }^{100}$

Perhaps this would be inconsequential if the smaller numbers imposed no duties on the larger community. ${ }^{101}$ Some cases suggested that issues of maintenance and tort liability were distinguishable from disputes over mere access. In the latter cases, no taxpayers' money was at stake and the only issue was whether a particular way would remain open, ${ }^{102}$ so that formal governmental "acceptance" need not be required. The owner who "dedicated" a roadway should be estopped from arguing that the general public could not "accept" for access purposes, ${ }^{103}$ but this had no necessary effect on the public purse. Governmental acceptance might be required in a liability context, however, where a governmental body (and derivatively, the entire citizenry) could be made respon-

97 Green v. Town of Canaan, 29 Conn. 157, 164 (1860) (officials are agents for public that has "accepted"); see also Reed v. Inhabitants of Northfield, 30 Mass. (13 Pick.) 94, 98 (1832) (public officials are responsible if they are aware of a defect in a road that the public has long used); Devenpeck v. Lambert, 44 Barb. 596 (N.Y. 1865) (interpreting a statute making a road public if it were so used).

3* 81 Conn. 408, 71 A. 361 (1908).

"Id. at $412-15,71$ A. at $363-64$.

${ }^{100} \mathrm{Id}$. at $414,71 \mathrm{~A}$. at 364 .

${ }^{201}$ See supra text accompanying notes 89-90; see also Way v. Fellows, 91 Vt. 326, 329, 100 A. 682, 684 (1917) (no public road unless officially adopted, citing cases concerning an obligation to maintain); Livingston, supra note 15, at 693 (noting the fear of liability in similar cases).

${ }^{102}$ See, e.g., Wood v. Hurd, 34 N.J.L. 87, 89-90 (1869).

${ }^{103}$ See id.; Smith v. City of San Luis Obispo, 95 Cal. 463, 470, 30 P. 591, 593 (1892); see also Tolliver v. Louisville \& N.R.R., 226 Ky. 132, 13510 S.W.2d 623, 624-25 (1928) (distinguishing public right of use from public duty to repair); Harrington v. City of Manchester, 76 N.H. 347, 349, 82 A. 716, 717-18 (1912). 
sible for some expense.

By the end of the century, however, many courts passed beyond even this bifurcated doctrine, and in a complete turnaround of earlier cases equating "acceptance" with official acts, held that the unorganized public's usage of a road could "accept" a road-even where the issue was governmental liability. ${ }^{104}$ This development is quite extraordinary: no one disputes that governmental authorities may decide for their constituencies to establish and maintain a roadway, but these doctrines placed the decision in the hands of an unknown set of persons, perhaps few in number, whose sporadic use of a roadway foisted responsibilities on all their fellow citizens. ${ }^{105}$

Why allow unorganized individuals to bind their governments to "accept" roadways? The chief idea seems to have been to protect injured parties' expectations. In Benton v. City of St. Louis, ${ }^{106}$ the plaintiff's deceased had drowned in a sinkhole in a walkway that the city had never formally accepted. After repeating the usual view that the city was only an agent for its inhabitants, the court remarked that because to all appearances this was a public sidewalk, the city would be estopped from denying it-even though no official had ever done anything to suggest its public acceptance. ${ }^{107}$ The appearance of publicness, then, as much as public use, fixed "acceptance"; as in Phillips, even sporadic public use would constitute "acceptance" where the users were those "naturally expected."108

This still leaves a puzzle: what characteristics make a sidewalk or an access road "appear" public to the ordinary observer? A few

104 B. Elliotr \& W. ElliotT, supra note 49, § 154, at 164 (general public can accept for all purposes); $c f$. Way v. Fellows, 91 Vt. 326, 329, $100 \mathrm{~A}$. 682, 684 (1917) (road not open to public if not "accepted" by official acts).

105 The notion is doubly extraordinary in light of other common 19th-century doctrines disallowing even official acts or neglect from estopping or otherwise binding governments. See, e.g., People v. Brown, 67 Ill. 435, 438 (1873) (while the doctrine of estoppel may apply between individuals, it does not apply to the state, since "[a] great and overshadowing public policy of preserving [the state's] rights, revenues and property from injury and loss by the negligence of public officers, forbids the application of the doctrine"). See generally Annot., 1 A.L.R.2d 338, 344-46 (1948) (applicability of estoppel against the government and its agencies).

${ }^{108} 217$ Mo. 687, 118 S.W. 418 (1909). A British case cited earlier, Rex v. Inhabitants of Leake, 5 B. \& Ald. 469, 482, 110 Eng. Rep. 863, 868 (K.B. 1833), suggested another reason that may have seemed inapplicable to a large country like the United States: each village's residents would be reciprocally benefited if all villages had to maintain local ways used by the public.

107217 Mo. at 706,118 S.W. at 423.

${ }^{108}$ Phillips v. City of Stamford, 81 Conn. 408, 414, 71 A. 361, 364 (1908). 
cases suggested that those things appear to be public that the public needs. Manderschid v. City of Dubuque, ${ }^{109}$ for example, concerned tort liability for a bridge that had fallen into disrepair. In holding that the general public's use counted as "acceptance," the court said (over a strong dissent) that the city has a duty to maintain those things that the public "needs."110 But again, what is it about a bridge that suggests that the public needs it? To make such an assertion, one requires a prior conception of the things that ought to be open to the public. The waterway cases too had controversies suggesting that some properties ought by nature to be public.

\section{B. Waterways and the Definition of "Public": The Issue of Legislative Power}

As in the roadway cases, some early nineteenth-century commentators thought that "public" control of waterways and submerged lands meant a public organized into governmental bodies. Joseph Angell, in his 1826 book on tidelands, presented a standard theory of crown ownership of submerged "trust" lands. According to Angell, even though the king himself had no power to grant these lands free from the public trust rights of navigation and fishing, ${ }^{111}$ Parliament had the power to alienate trust rights, and could place fishing rights in private hands. ${ }^{112}$ American legislatures had succeeded to the position of Parliament, and had the same ability. ${ }^{113}$

Angell believed that this distinction between crown and legislature existed because the legislature (unlike the crown) is the same thing as the public itself. One could not deny the legislature's authority to relinquish the right without denying that the right belonged to the public in the first place. ${ }^{114}$ Implicit in this analysis, of

10929 Iowa 73 (1870).

110 Id. at 85; see also Reed v. Inhabitants of Northfield, 30 Mass. (13 Pick.) 94, 97-98 (1832) (age and importance of highways bears on their being considered "public").

$111 \mathrm{~J}$. ANGELL, supra note 6, at 21,33 (king cannot sell waterways free of trust purposes).

${ }^{112}$ Id. at 106-07. Angell was speaking here of a grant of a private right of fishing, and thus it was unclear whether he thought that even Parliament could divest the public of its rights to use waterways for navigation, though his explanation of parliamentary control is stated in very broad terms. See infra text accompanying note 114.

113 J. ANGELL, supra note 6, at 106-07.

${ }^{114} \mathrm{Id}$. at 107. Angell also mentioned by analogy the closing of a road. There may be an implicit theory of representation in Angell's view, namely that the legislature was a "picture" or literal "re-presentation" of the people, and was thus identical to the people. For the "picture" theory of representation-a common one in 18th-century political discourse-see 
course, was a disavowal of any status that the "unorganized" public might have against its own legislature, which served as the public's necessary mouthpiece. The people might be sovereign, but they could act only through their agent legislatures. The New York courts for much of the century emphatically affirmed this plenary legislative authority, stating that the legislature had succeeded to the authority of both the king and Parliament in navigable waterways. Subject only to the paramount federal control of commerce, the legislature's ability to act for the public was complete-up to and including alienation of public rights. ${ }^{115}$

But even as Angell stated this theory of legislative authority, and even as courts acted upon it, a second theory was making an appearance in the case law. The 1821 decision in Arnold $v$. Mundy ${ }^{116}$ began the discussion of a "public trust" controlling the disposition of submerged lands. ${ }^{117}$ Arnold involved the validity of private property rights in some submerged lands whose purported title traced back to royal grants to the colonial New Jersey proprietors. The court stated the standard theory that the crown was unable to alienate trust lands, but went on to assert that even the legislature was limited in its capacity to dispose of these lands. ${ }^{118}$ The legislature could alter trust properties for the sake of improving the public's uses; but even it could not grant away trust lands so as to "divest[] . . . all the citizens of their common right."119 "Such a grant," said Chief Justice Kirkpatrick, "would be contrary to the great principles of our constitution, and never could be borne by a free people."120 Apparently because of the inherently public character of these lands, even the sovereign legislature could

Hanna Pitkin, The Concept of Representation 60-61 (1972).

11 Lansing v. Smith, 4 Wend. 9, 21-22 (N.Y. 1829); see also Langdon v. Mayor of New York, 93 N.Y. 129, 155-56 (1883) (legislative authority over tidelands was plenary, holding them as "absolute owner, and in no sense a trustee" except insofar as all acts were to be for the public benefit); People v. New York \& Staten Island Ferry Co., 68 N.Y. 71, 77-78 (1877) (citing Angell). New York may have been particularly sensitive on this issue. Alienation of submerged lands, the "water lots," had historically made up an important part of the authority of the City of New York; the city's powers in turn were increasingly subordinated to the state legislature during the course of the 19th century. See generally HENDRICK HaRTOG, Public Property and Private Power: The Corporation of the City of New York in AMERICAN LAW, 1730-1870, at 48-52, 206-07, 223-24 (1983).

1166 N.J.L. 1 (1821).

117 MacGrady, supra note 9, at 590-91. The case was the apparent authority for Chief Justice Taney's discussion of a "public trust" in tidelands two decades later in Martin v. Waddell, 41 U.S. (16 Pet.) 367 (1842), which involved a very similar fact situation.

1186 N.J.L. at 12-13, 77-78.

119 Id. at 13. For a slightly different formulation, see id. at 78 .

120 Id. at 13,78 . 
not make such a grant. ${ }^{121}$

Within a few years, the New Jersey courts backed away from this position, even citing New York cases to reassert the legislature's plenary control over submerged lands. ${ }^{122}$ In the meantime, when the United States Supreme Court, in Martin v. Waddell, held that title in some submerged lands could not be derived from a royal grant, it discussed but maneuvered around Arnold's public trust position. ${ }^{123}$ But Arnold's "trust" theory, under which the unorganized public had property rights that could override even the acts of the public's own representatives, enjoyed a spectacular revival at the end of the century in Illinois Central Railroad $v$. Illinois. ${ }^{124}$

The backdrop to this most famous assertion of the public trust theory was a pair of acts by the Illinois legislature: first it had granted to a railroad the submerged lands all along Chicago's lakefront; then it repented and revoked the grant. The question before the Supreme Court concerned the status of the initial grant: if it were valid, the legislature could not rescind it without compensation. ${ }^{125}$ But according to the Court, this first grant was indeed revocable. The legislature could not permanently alienate these lands, except in the service of trust purposes for which they were held. ${ }^{128}$ An attempted grant of this sort, said Justice Field (in a passage remarkably free of supporting authority), "would be held, if not absolutely void on its face, as subject to revocation."127

121 Id. at 78.

122 Gough v. Bell, 22 N.J.L. 441, 457, 467, 473 (1850), aff'd, 23 N.J.L. 624 (1852); Stevens v. Paterson \& N.R.R., 34 N.J.L. 532, 549-52 (1870). In the recent past the New Jersey court has revived its debate with itself on the legality of privatizing the waterfront. See Matthews v. Bay Head Improvement Ass'n, 95 N.J. 306, 317-19, 471 A.2d 355, 360-61 (1984) (where Arnold v. Mundy once again receives favorable treatment).

${ }^{123}$ Martin v. Waddell, 41 U.S. (16 Pet.) 367, 417 (1842). Justice Thompson offered a more extensive (and unfavorable) discussion of Arnold. See 41 U.S. (16 Pet.) at 419-21 (Thompson, J., dissenting).

124146 U.S. 387 (1892).

${ }_{125}$ The case bears a striking similarity to Fletcher v. Peck, 10 U.S. (6 Cranch) 87 (1810), in which Georgia's legislature was held unable to rescind large land grants made by a previous legislature. The similarity is noted in Currie, The Constitution in the Supreme Court: The Protection of Economic Interests, 1889-1910, 52 U. CHI. L. REv. 324, 331-32 (1985).

128 146 U.S. at 453.

${ }^{127}$ Id. None of the authorities that Field cited had overturned a legislature's power to alienate trust lands. See Currie, supra note 125, at 332. Indeed, he cited People v. New York \& Staten Island Ferry Co., 68 N.Y. 71 (1877); in dictum this case had explicitly denied the trust theory. See supra text accompanying note 115 for New York's position supporting legislative authority over tidelands. Field's strongest authority was Kirkpatrick's opinion in the much battered Arnold v. Mundy. 
He ignored the express safeguards to public navigation incorporated into the grant, ${ }^{128}$ and compared a purported divestment of the public's trust rights to a government's effort to divest itself of the police power-equally invalid and ineffectual. ${ }^{129}$

Illinois Central sparked a new line of state "public trust" jurisprudence. Wisconsin was particularly active in this area, citing Illinois Central to hold that waterways were necessarily subject to public rights. ${ }^{130}$ Moreover, Wisconsin's doctrine conferred property-like interests on the general public over against its governmental officials and the elected legislature. The public's interest in navigation was held to override officially sanctioned efforts to destroy navigable waters for the sake of other purposes, such as drainage for agriculture or public health. ${ }^{131}$ Florida too had several public trust cases, some of which suggested that the general public's rights acted as a limitation on legislative authority over submerged lands. ${ }^{132}$ Even New York withdrew temporarily from its

${ }^{128} 146$ U.S. at 406 n.I.

128146 U.S. at 453; see also Stone v. Mississippi, 101 U.S. 814, 817 (1880) (a state cannot contract away its police power). This again harks back to Fletcher v. Peck, where Chief Justice Marshall noted that a legislature could repeal the ordinary legislation of an earlier legislature, suggesting that one legislature could not tie the hands of a later one. 10 U.S. (6 Cranch) at 135; see also Currie, supra note 125, at 333 n.62.

130 Priewe v. Wisconsin State Land \& Improvement Co., 93 Wis. 534, 550, 67 N.W. 918 , 922 (1896) (citing Illinois Central, finds state holds submerged lands in trust for the public, and cannot authorize its use except for trust purposes); see also McLennan v. Prentice, 85 Wis. 427, 444, 55 N.W. 764, 770 (1893) (private conveyance of submerged lands is subject to public trust, citing Illinois Central).

${ }^{131}$ In re Crawford County Levee \& Drainage Dist. No. 1, 182 Wis. 404, 408-12, 196 N.W. 874, 875-77, cert. denied, 264 U.S. 598 (1924) (navigation superior to agricultural drainage, citing Northwest Ordinance duties); In re Dancy Drainage Dist. 129 Wis. 129, 13940, 108 N.W. 202, 205 (1906) (drainage commissioners not authorized to destroy navigation, citing Priewe on "duty of legislature" to protect); Priewe, 93 Wis. at 550, 67 N.W. at 922; City of Milwaukee v. State, 193 Wis. 423, 453-56, 214 N.W. 820, 830-32 (1927) (grant for harbor improvement does not violate public trust, under the circumstances); cf. In re Trempealeau Drainage Dist., 146 Wis. 398, 407-08, 131 N.W. 838, 840 (1911) (agricultural drainage is permissible where navigability is improved). Crawford County cited the Northwest Ordinance as a higher authority for saying that even the Wisconsin legislature was bound by the public trust. This strategy-referring the public trust to some higher, constitutive document-was recently echoed in Borough of Neptune City v. Borough of Avon-by-the-Sea, 61 N.J. 296, 308-09, 294 A.2d 47, 54-55 (1972), where the municipality was viewed as receiving its control over beaches from the state. As trustee for all the state's people, the municipality could not restrict access to its residents.

${ }^{132}$ This historical development is traced in Rosen, Public and Private Ownership Rights in Lands Under Navigable Waters: The Government/Proprietary Distinction, 34 U. FLA. L. REv. 561, 588-610 (1982). These cases began with an Illinois Central-like conception of the public trust as a limitation on the legislature's ability to grant the seashore to private persons. However, the courts withdrew from this position by the 1920 s, permitting the legislature to exercise discretion over alienation of tidal or submerged lands. 
hardline doctrine of absolute legislative authority over submerged lands. ${ }^{133}$

The public trust doctrine in waterways, then, like the prescriptive doctrines for roads, gravitated between two different definitions of the public: the public as governmental authority, whose ability to manage and dispose of trust property is plenary, and the public at large, which despite its unorganized state has propertylike rights in the lands held in trust for it-rights that may be asserted even against its own representatives. This dualism has reappeared in the current debate. Joseph Sax, a chief spokesman for a "public trust," takes the former view of plenary legislative authority over trust lands, at least with respect to their ultimate disposition; but others suggest that his ideas go beyond this, transforming "public trust" into a theory that confers property rights on the public at large. ${ }^{134}$ On such a theory, even the legislature itself cannot divest the public of its rights.

This version of rights-rights vesting in an unorganized public-departs strikingly from the ordinary view of neoclassical economics. The public at large is a nonexclusive body, and it is puzzling to see how such a body could exercise the most fundamental attributes of ownership: investment or management (since no individual can capture the full gain of his efforts), or even alienation (since no potential purchaser would have a clear seller with whom to deal). For assistance in this puzzle, I turn to the least used of the public property doctrines: custom.

\section{Custom and the Concept of a Managed Commons}

Unlike prescription or public trust doctrine, custom was used in only a few American states to claim a right to use roads, pathways, and tidelands. ${ }^{135}$ Joseph Angell treated customary rights as a

1ss See Long Sault Dev. Co. v. Kennedy, 212 N.Y. 1, 10, 105 N.E. 849, 852 (1914) (state may repeal grant in submerged lands when the public purpose is insufficient, citing Illinois Central); Coxe v. State, 144 N.Y. 396, 406, 39 N.E. 400, 402 (1895) (notes inalienable trust doctrine in tidelands despite contrary doctrine of New York, citing Illinois Central); cf. People v. Steeplechase Park Co., 218 N.Y. 459, 478, 113 N.E. 521, 526 (1916) (distinguishing Illinois Central in case of small grant of tidelands). These cases set off a small scholarly debate. Compare Riggs, The Alienability of the State's Title to the Foreshore, 12 Colum. L. REv. 395 (1912) (foreshore absolutely alienable by legislature), with Parsons, Public and Private Rights in the Foreshore, 22 Colum. L. REv. 706 (1922) (foreshore owned by public at large, government a mere trustee).

134 See supra note 39; see also supra text accompanying notes 35-39.

195 New Hampshire was the chief state to recognize customary claims. See, e.g., Nudd v. Hobbs, 17 N.H. 524 (1845) (customary right of passage); see also Knowles v. Dow, 22 N.H. 387 (1851) (customary right to deposit seaweed on plaintiff's land); cf. Graham v. 
type of prescriptive right, but they differed from ordinary private prescriptive rights in that they were enjoyed not by individuals as such but only as members of a specific locality. ${ }^{136}$ For the same reason, customary claims also differed from claims of public prescription or "public trust," which benefited not specific communities but the public at large. Yet in an important way customary claims resembled the doctrines vesting property-like rights in the general public: custom benefited people whose precise identity was unknown and indefinite. Thus these claims too lacked the exclusivity that normally accompanies individual property entitlements. ${ }^{137}$

Customary claims originated in ancient British legal doctrine, whereby residents of given localities could claim rights as "customs of the manor" overriding the common law. ${ }^{138}$ Blackstone noted that some localities had their own customary rules for such matters as inheritance and the time and manner of rental payments. ${ }^{139}$ To be held good, a customary right must have existed without dispute for a time that supposedly ran beyond memory, and it had to be well-defined and "reasonable."140 In British law, custom had traditionally supported a community's claims to use a variety of lands in common: for example, manorial tenants' rights to graze animals, gather wood, or cut turf on the manor commons. ${ }^{141}$ Though many of these rights had vanished by the nineteenth century, ${ }^{142}$ some communities' customary claims to use lands persisted. Roadway

Walker, 78 Conn. 130, 61 A. 98 (1905) (customary claim to right of passage disallowed); Freary v. Cooke, 14 Mass. 488 (1779) (customary right to private fishery denied, though customary rights apparently accepted in principle); Van Rensselaer v. Radcliff, 10 Wend. 639 (N.Y. Sup. Ct. 1833) (customary rights generally contrary to American law, but recognized on specific Livingston \& Van Rensselaer manors). For a review of major customary doctrine up to the 1930 s, see Gillies v. Orienta Beach Club, 159 Misc. 675, 289 N.Y.S. 733 (Sup. Ct. 1935), discussed in 21 Minn. L. Rev. 91, 107 (1936).

13e J. ANGELL, supra note 6, at 87-88 (customary claims a variant of prescription, for communities); see also $2 \mathrm{~W}$. Blackstone, supra note 1, at *263.

${ }^{137} 2$ W. Blackstone, supra note 1 , at *263 (a custom "is applied to the place in general, and not to particular persons").

${ }_{138}$ Id. at *90-91, *95-97 (development of customary rights from feudal tenure); 8 HaLSBURy's Laws of ENGLAND § 476, at 275-76 (Lord Simonds 3d ed. 1954); see also Donald Denman, Tenant Right Valuation in History and Modern Practice 18 (1942).

138 See 1 W. Blackstone supra note 1 , at *74-75; 2 id. at *97. Some of these customary rights continued into the 19th century. See D. Denman, supra note 138, at 84-85; see also id. at 87-107 (listing customary rights).

140 8 Halsbury's LaWs of ENGLAÑ, supra note 138, \& 477, at 276-77; See also 1 W. Blackstone, supra note 1 , at *76-78. But see infra note 145 (discussing the somewhat artificial character of "time of memory").

${ }_{141} 2 \mathrm{~W}$. BLAckstone, supra note 1, at *32-35.

${ }_{142}$ See, e.g., Dean \& Chapter of Ely v. Warren, 2 Atkyns 189, 26 Eng. Rep. 518 (Ch. 1741) (statutory enclosure ends common right to take turf); see also infra note 154 and accompanying text. 
use was among the surviving customary claims, but the most notable were for recreational uses-maypole dances, horse races, cricket matches, and the like. ${ }^{143}$

In the early nineteenth century, some American courts seemed willing-albeit reluctantly - to acknowledge a limited doctrine of customary claims, ${ }^{144}$ even though, as one court said, customary law was "prejudicial" to agriculture, and "uncongenial with the genius of our government and with the spirit of independence" of our farmers. ${ }^{145} \mathrm{By}$ the end of the century, however, American courts appeared hostile to customary claims in principle, and they seemed particularly disturbed that customary claims benefited members of specific communities.

Graham v. Walker, ${ }^{148}$ for example, was a trespass action in which the defendant claimed to be using a customary right of way linking two communities. The Connecticut Supreme Court gave several reasons for denying such a right: in a state that had always had a recording system, even long usage of land could not demonstrate a "lost grant" (the normal fiction for prescriptive rights). In any event the purported grantee was of too "fluctuating" a character. ${ }^{147}$ Most interesting was a third rationale: the Graham court

143 Hull v. Nottinghan, 33 L.T.R. 697 (Ex. D. 1876) (customary right to have maypole dance and other recreation on plaintiff's land); Mounsey v. Ismay, I Hurl. \& Colt. 729, 158 Eng. Rep. 1077 (Q.B. 1863) (customary right to hold annual horserace on plaintiff's land); Fitch v. Rawling, 2 H. Black 393, 126 Eng. Rep. 614 (K.B. 1795) (customary right to play cricket on plaintiff's land); Abbot v. Weekley, 1 Lev. 176 (17 Car. II), 83 Eng. Rep. 357 (K.B. 1665) (customary right to dance on plaintiff's land upheld). Blackstone cited Weekley to distinguish custom from ordinary prescription. $2 \mathrm{~W}$. Blackstone, supra note 1, at ${ }^{*} 263$.

${ }_{14}$ See supra note 135; see also Pearsall v. Post, 20 Wend. 111, 123-25 (N.Y. Sup. Ct. 1838), aff'd, 22 Wend. 425 (N.Y. 1839) (no customary rights to land or to deposit manure on plaintiff's land).

${ }^{145}$ Van Rensselaer v. Radcliff, 10 Wend. 639, 649 (N.Y. Sup. Ct. 1833). Some courts also questioned customary claims because they thought there was no such thing as "immemorial usage" in the United States. See, e.g., Ackerman v. Shelp, 8 N.J.L. 125, 130 (1825) (New Jersey law cannot go back to the reign of Richard I, the conventional date of immemorial usage). One theory of customary rights was that they stemmed from a special local law preceding and superior to the common law; according to some courts, this was impossible in the United States, since the common law had been introduced here at the time of settlement. See, e.g., Delaplane v. Crenshaw \& Fisher, 56 Va. (15 Gratt.) 457, 470-71 (1860). "Time immemorial" was obviously a fiction even in England, however, since some relatively modern usages were upheld as good customs there. See, e.g., Fitch v. Rawling, 2 H. Black 393, 126 Eng. Rep. 614 (1795) (custom of holding cricket matches upheld); see also The Public and the Foreshore, 139 The Law Times 381, 383 (London 1915) (some customary rights are of recent origin).

1478 Conn. 130, 61 A. 98 (1905).

147 Id. at 132-33, $61 \mathrm{~A}$. at 99. However, similar objections would have applied with even greater force to an "implied dedication" to the public at large, a matter on which the Connecticut court was much more lenient. This was shown three years later in Phillips v. City of Stamford, 81 Conn. 408, 71 A. 361 (1908), which permitted the general public to "accept" a 
noted that such customary rights would favor "forms of communities unknown in this State."148 As with earlier case law on custom, this remark undoubtedly reflected a hostility to the feudal and manorial basis of customary claims. ${ }^{148}$ But it also may have focused precisely on the informal character of the "community" claiming the right: if a community made claims in a corporate capacity, it would have to be organized in a form authorized by the state.

This point was made even more forcefully in Delaplane $v$. Crenshaw \& Fisher, ${ }^{180}$ an earlier Virginia case involving a claimed "customary" right of grain inspectors to be paid in kind from inspected goods. The state constitution vested lawmaking authority in the legislature, said the court, whereas a right based on custom would permit "comparatively . . . few individuals" to make a law binding on the public at large, encroaching on the people's right to be bound only by laws passed by their own "proper representatives."151 Indeed, if an unorganized community could claim to act authoritatively through custom, then custom could displace orderly government.

These essentially political or constitutional anxieties about customary rights suggest their real character. The fear was that customary claims might allow informal, unofficial practice to supplant established government. But in a sense custom does precisely this. It was a commonplace among British jurisprudes that a general custom, the "custom of the country," is none other than the common law itself. ${ }^{182}$ From this perspective, custom is the method through which an otherwise unorganized public can order its affairs authoritatively.

Custom thus suggests a means by which a "commons" may be managed-a means different from exclusive ownership by either individuals or governments. The intriguing aspect of customary rights is that they vest property rights in groups that are indefinite and informal, yet nevertheless capable of self-management. Custom might be the medium through which such an informal group acts generally; thus, the community claiming customary rights was really not an "unorganized" public at all.

pathway by use.

14878 Conn. at $133,61 \mathrm{~A}$. at 99.

149 Id. (no feudal system here comparable to Britain's); see supra text accompanying note 145 .

${ }^{280} 56$ Va. (15 Gratt.) 457 (1860).

181 Id. at 475.

${ }^{152} 1 \mathrm{~W}$. BLAcksToNE, supra note 1, at *67 ("General customs; which are the universal rule of the whole kingdom . . . form the common law."). 
From a resource-management perspective, a group capable of generating its own customs ought to be a less objectionable holder of "public property" than the unorganized general public, because a customary public comes closer to the management capacities of a government. If this is so, then the claims for customary rights should be stronger, not weaker, than the claims of the general public in roads and waterways. Even though the American courts rejected customary rights on grounds of constitutional policy, one can see the logic of the English pattern, where customary claims encompassed a considerably broader range of property than roads and waterways. ${ }^{163}$

By the nineteenth century, even in Britain, the enclosure of manorial commons had largely eradicated customary claims for consumptive uses such as pasturing and woodgathering. ${ }^{154}$ But customary rights suggested that even with respect to scarce resources, ${ }^{155}$ a commons need not be a wasteland of uncertain or conflicting property claims. Customary use of the medieval commons, even for consumptive uses, had been hedged with restrictions limiting depletion of resources. ${ }^{158}$ This pattern continued into the nineteenth century, insofar as the courts recognized customary claims. A customary right to take soil from a commons, for example, would be permitted only if it included limitations consistent with the tenement's ability to recover; ${ }^{157}$ otherwise the custom

153 See supra text accompanying notes 141-43.

134 8 Halsbury's Laws of England, supra note 138, $\S 498$, at 288; see, e.g., Dean \& Chapter of Ely v. Warren, 2 Atkyns 189, 26 Eng. Rep. 518 (Ch. 1741) (right to cut turfs ceases if land enclosed by parliamentary act). For the enclosures generally, see G. MingaY, English Landed Society in the Eighteenth Century 179-88 (1963). In American jurisdictions that permitted customary claims, it was nevertheless commonplace that custom would not support "usufruct." See, e.g., Nudd v. Hobbs, 17 N.H. 524, 527 (1845) (no customary rights to take seaweed); Pearsall v. Post, 20 Wend. 111, 123-25 (N.Y. Sup. Ct. 1838), aff'd, 22 Wend. 425 (N.Y. 1839) (custom would not support right to store things on another person's property).

${ }^{185}$ Non-scarce resources seem to be what the Romans called res nullius, property that belonged to no one; the term applied particularly to wildlife, which merely awaited reduction to owmership, perhaps without detriment to others. See Coquillette, supra note 9, at 803 n.196; MacGrady, supra note 9, at 518 n.24, 533; Winett, supra note 9, at 31-32.

188 Carl. Dahlman, The Open Field System and Beyond: A Property Rights Analysis of AN Economic Institution 23, 101 (1980); Blum, The Internal Structure and Polity of the European Village Community from the Fifteenth to the Nineteenth Centuries, 43 J. MoD. Hist. 541, 542 (1971) (commons had restrictions on planting of crops and raising of animals, to prevent overuse); Ciriacy-Wantrup \& Bishop, "Common Property" as a Concept in Natural Resources Policy, 15 Nat. Resources J. 713, 719 (1975).

${ }_{137}$ Clayton v. Corby, 5 Q.B. 415, 419-20, 114 Eng. Rep. 1306, 1307-08 (1843) (customary right to take clay for commercial purposes held improper because incompatible with renewal of soil); Wilson v. Willes, 7 East 121, 125-26, 103 Eng. Rep. 46, 49 (K.B. 1806) (customary right to take turf held too uncertain in amount, unlike a customary right that 
would be denied as "uncertain" or "unreasonable."158

The concept of a managed commons also suggests that under some circumstances property might be more valuable as a commons than in individual hands, because the administrative costs of customary management are low relative to those of an individual property system. ${ }^{159}$ While European legal and political systems were still weak, individual ownership of pasturage and woodlands might have required a prohibitively expensive policing system-certainly one more expensive than communal custom. ${ }^{160}$ In an example closer to home, during the early years of settlement in the western United States, settlers treated land, water, and other resources as a commons, and managed them through their own customs. It was only with the arrival of increasing numbers of claimants with conflicting claims that customs were formalized into law. ${ }^{161}$

Given that custom may be an informal technique for managing a commons, let us turn back to roads and waterways to which the public had access, ostensibly as an "unorganized" commons. Were the travelers on roads and waterways really an unorganized group? Angell and Durfee's 1857 treatise on highways suggests that they were not. It includes many pages on "the law of the road," including travel on roads, canals, railroads, and navigable rivers. ${ }^{162}$ Travelers were to keep to a particular side, and yield for one or another

improves land).

${ }^{288}$ See supra note 157. Recreational uses of commons areas sometimes had to meet similar requirements. See, e.g., Bland v. Lipscombe (Q.B. 1854), reported in Race v. Ward, 4 Ellis \& Blackburn 702, 713 n.(c), 99 Rev. Rep. 702, 710 n.(2) (Q.B. 1855) (distinguishing customary right to dance in common from right to take fish-latter "would be very injurious to the owner and of but little benefit to the inhabitants").

150 See Cheung, The Structure of a Contract and the Theory of a Non-Exclusive Resource, 13 J.L. \& EcoN. 49, 64 (1970) (common property regime costs less than exclusive rights, though returns may also be less); cf. Ciriacy-Wantrup \& Bishop, supra note 156, at 720 (returns can be higher in commons that are better managed than individual property).

${ }^{180}$ C. Dahlman, supra note 156, at 116-17; Cheung, supra note 159, at 64.

${ }_{181}$ Anderson \& Hill, supra note 28, at 169-78. Much the same kind of development from custom to formal law occurred with California gold mining claims on unpoliced federal public lands, where customary patterns set by the early miners provided a baseline for later formalized mining law. See McCurdy, Stephen J. Field and Public Land Law Development in California 1850-1866: A Case Study of Judicial Resource Allocation in Nineteenth-Century America, 10 LAw \& Soc'y Rev. 235, 240-46 (1976); Umbeck, A Theory of Contract Choice and the California Gold Rush, 20 J.L. \& Econ. 421, 434-37 (1977) (custom set early pattern, then formalized). Somewhat similarly, David Konig has described the sloppiness of the policing system for New England land titles, and reliance on community custom for land records, prior to the rapid settlement in the later 17 th century. See Konig, supra note 28 , at 148.

${ }^{262}$ J. ANGell \& T. DURFEE, supra note $45, \S \S 327-449$. 
use, and move at a moderate pace. These rules derived in America from statute, but in England from-what else?-custom. ${ }^{163}$

Moreover, the confinement of roads and waterways to limited areas suggests that travel and transport on them were literally kept within bounds. ${ }^{164}$ There was also a considerable body of common law about what uses-if any-travelers might make of the bordering property; road users, for example, could go around impassable spots, but they had to keep their detours as close as practicable to the existing road, and use alternate routes if possible. ${ }^{165}$ Similar rules restrained the uses of waterways: navigation was deemed superior to other waterway uses such as fishing, but sailors had to avoid disrupting fish nets unnecessarily. ${ }^{168}$ Such rules limited impositions on others, while permitting public use of the travel lanes. They suggested that roads and waterways were "managed commons," where customary practices ameliorated congestion and external harms, and where alternative property regimes might not have been worth the expense, so long as the country was relatively undeveloped.

Indeed American roadway case law suggested a view of the "public" and its members that is at odds with the picture of a heedlessly self-interested and atomized collection of individuals. The mid-nineteenth-century courts sometimes denied public claims in fear that they might "be perverting neighborhood forbearance and good nature"167 and uprooting the generous habits and customs of the people ${ }^{188}$ - characteristics that the courts clearly wished to foster, just as they wished to eschew "churlish" practices. ${ }^{169}$ This in turn suggested that the law was a vehicle to uphold a level of civilized behavior already existing in the people. ${ }^{170}$

${ }^{163} I d . \S \S 327-32$ (usages); id. $\S 333$ (custom).

${ }^{164}$ See infra text accompanying notes 191-96.

185 B. ElliotT \& W. Elliotr, supra note 49, §§ 12-14; see also Campbell v. Race, 61 Mass. (6 Cush.) 408, 413 (1851); Morey v. Fitzgerald, 56 Vt. 487, 490 (1884) (road users could go extra viam, but had to use another route if reasonably available). Campbell described this as an "incidental" burden on property to be expected in a "civilized community." 61 Mass. (6 Cush.) at 412.

${ }^{168}$ Post v. Munn, 4 N.J.L. 68, 70, 72 (1818).

187 Pearsall v. Post, 20 Wend. 111, 135 (N.Y. Sup. Ct. 1838).

186 See, e.g., Starr v. People, 17 Colo. 458, 462, 30 P. 64, 66 (1892); Warren v. President of Jacksonville, 15 Ill. 236, 241-42 (1853) (references to generous customs).

${ }^{160} \mathrm{~J}$. ANGell \& T. Durfes, supra note 45, § 151; see also Gore v. Blanchard, 96 Vt. 234, 240, 118 A. 888,891 (1922).

${ }^{170}$ This same conception informed the American rejection of the British doctrine of "ancient lights," permitting prescriptive rights to light and air; to allow such rights, it was said, would encourage neighbors to build prematurely, for no purpose except to keep their 
The nineteenth-century American courts allowed claims by the public at large, but rejected customary rights and the unorthodox communities associated with those customary rights. This antipathy, however, tended to obscure the point that small and unorthodox communities are not the only ones bound together by custom. An entire populace may have customs as well, as Blackstone and others recognized when they called the common law the "custom of the country."171 The concept of a managed but completely open commons presupposes just such a populace-one that behaves according to customs of civic care, and with some regard for the resources it uses. Such a concept of the citizenry, after all, was familiar to nineteenth-century jurisprudence, given the serious discussion during the American revolutionary and constitutional periods of "republican virtue" - the individual self-restraint and civic regard for the greater good that was thought essential to any democratic regime. ${ }^{172}$

The managed and organized aspect of customary rights, then, casts new light on the public rights in roads and waterways. Like the customary rights of traditional communities, travel and commercial transport occur where even the public-at-large can manage itself and prevent waste of a resource; the "unorganized public" begins to seem more like a civilized and self-policing group. Custom, in short, can tame and moderate the dreaded rule of capture that supposedly tends to turn every commons into a waste. Indeed, while our normal means of taming the rule of capture is a private property regime, that too may sometimes be governed only by custom. We see this, to take a prosaic example, in the customs that permit a kind of "property" in a place in line. ${ }^{173}$ Indeed a private

neighbors from having light and air for the prescriptive period. See Parker \& Edgarton v. Foote, 19 Wend. 309, 318 (N.Y. Sup. Ct. 1838); cf. M. HoRwiTz, supra note 25, at 46-47 (interpreting the American rejection of "ancient lights" as a part of a pro-development ideology).

${ }^{173}$ See supra text accompanying note 152.

172 See Gordon Wood, The Creation of the American Republic 1776-87, at 118-24 (1969); see also J.G.A. Pocock, The Machiavellian Moment: Florentine Political Thought and the Atlantic Republican Tradition 506-07 (1975). For the continuation of this discussion from the constitutional period into the 19th century, see J. Pocock, supra, at 526-45. See also Campbell v. Race, 61 Mass. (7 Cush.) 408, 412 (1851) (reference to burdens of living in civilized community).

${ }^{173}$ See On the Pressures and Politics of Waiting in Line, N.Y. Times, Feb. 11, 1982, at $\mathrm{C} 1, \mathrm{C} 7$, col. 1 (places staked in line, even bought and sold). The economist Harold Demsetz has written a celebrated article arguing that a system of private property develops as a response to scarcity. See Demsetz, Toward a Theory of Property Rights, 57 AM. Econ. REv. 347, 350-53 (Papers \& Proceedings 1967). But his chief example shows Indian hunters developing informal customs, and it was apparently through custom that this group replaced the 
property regime itself - whether governmental or customary-may be understood as a managed "commons"-a meta-property held in common by those who understand and follow its precepts. In a sense, a movement toward private property is a movement from a "commons" in a physical resource to a "commons" in the social structure of individualized resource management. ${ }^{174}$

In American public property doctrine, one version of this movement was the saga of the lesser public trust right, fishing. Fishing may have been less controllable by customary practice than was road use; ${ }^{175}$ perhaps for this reason, nineteenth-century jurisprudes always viewed fishing as secondary to navigation, ${ }^{176}$ and as subject to a considerable degree of privatization, despite their rhetoric of public fishing rights. ${ }^{177}$

The rhetoric of "publicness" may have originated in perception of the "plenitude" of fish. ${ }^{178}$ The falsity of this perception was

earlier unmanaged "commons" in wildlife with an informal regime of private or rather family-based "property."

174 Remarks of J. Krier, Property Section presentation, The Tragedy of the Commons, American Association of Law Schools meeting (January 1985) (on Audiostat tape, Property). See also the remarks of F. Michelman and R. Ellickson, id. For the continued importance of customary practices and neighborliness even in a full-blown private property regime, see Ellickson, Of Coase and Cattle: Dispute Resolution Among Neighbors in Shasta County, 38 StAN. L. REv. 623, 671-73 (1986).

${ }^{128}$ Such customary limitations as there were were under attack in the 19th century. See, e.g., Gordon, The Economic Theory of a Common-Property Resource: The Fishery, 62 J. PoL. Econ. 124, 134 (1954) (attacks on informal monopoly). For the onslaught on native American customary fish management practices, see Arthur McEvoy, The Fisherman's Problem: Law and Ecology in the History of California's Fisheries 72-110 (unpublished manuscript, forthcoming); see also id. at 112-61 (on Asian and European immigrant practices).

${ }_{178}$ See, e.g., Post v. Munn, 4 N.J.L. 68 (1818); cf. Diana Shooting Club v. Husting, 156 Wis. 261, 268, 145 N.W. 816,820 (1914) (fishing is an incident to the right of navigation).

${ }^{177}$ For privatization of fishing rights, see infra notes 181-83 and text accompanying notes 204-06.

${ }^{178}$ In England, public fishing rights historically were confined to those waters within the ebb and flow of the tide-that is to say, to ocean going fish, which must have seemed limitless. See MacGrady, supra note 9, at 581-82 (describing doctrinal origin of the rule); see also Gordon, supra note 175, at 126 (describing later 19th-century British arguments for relaxing all fishing restrictions, on grounds that ocean fish were an inexhaustible resource). American definitions of "navigation" in some states extended public fishing rights to inland waterways, but there too the fish, like American wildlife generally, must have seemed inexhaustible. See MacGrady, supra note 9, at 589 (state ownership includes beds of all navigable waters); id. at 589-91 (state bed ownership the basis of public trust). The leading early case is Carson v. Blazer, 2 Binn. 475 ( $\mathrm{Pa} .1810)$ (rejects private fishing rights in river navigable in fact). See generally JAmes Tober, Who Owns The Wildlife? The Political Economy of Conservation in Nineteenth-Century America 3-5, 17 (1981) (describes Americans' belief in the limitless nature of a number of species that in fact soon succumbed to overhunting). 
recognized even in the nineteenth century ${ }^{179}$-and more in our own, where overfishing was our initial metaphor for the "tragedy of the commons." 180 In the nineteenth century, however, privatization must also have seemed ineffective to conserve fish. The most common method of privatization was allocation of ownership to the shore or bank owners. ${ }^{181}$ But since the fish moved about and no shore owner could claim any particular fish, ${ }^{182}$ the interest of each owner lay in appropriating the most fish for himself or for others who would purchase a fishing right from him. ${ }^{183}$ Thus, creating private fishing rights would merely shift the commons problem to another forum.

As a result, the most serious development of property in fishing has been the movement toward governmental management. As

179 J. TOBER, supra note 178, at 173 n.45 (19th-century interest in artificial fish breeding); Cheung, supra note 159, at 58-61 (commons in fishery leads to overfishing, thus depletion of the resource); see also Gordon, supra note 175, at 131.

${ }^{180}$ Ciriacy-Wantrup \& Bishop, supra note 156, at 722 (Gordon's 1954 article on fishing, supra note 175 , originated the literature on the "tragedy of the commons").

181 Technically a riparian owner's control over fishing followed from ownership of the subsoil. In some states the riparian owner did not own the subsoil; in states where the riparian owner did own the subsoil, his rights were sometimes subject to the public's navigation rights, but not to other public rights such as fishing. Compare, e.g., Schulte v. Warren, 218 Ill. 108, 75 N.E. 783 (1905) (public navigation easement does not extend to hunting and fishing), with Collins v. Gerhardt, 237 Mich. 38, 211 N.W. 115 (1926) (public has the right to fish in navigable streams even though the streambed belongs to riparian owner). See also the criticism of Collins in Note, The Right to Fish in Fresh-water Streams, 25 MicH. L. REv. 654 (1927). English law permitted private ownership of fishing rights, either by grant or by prescription. See J. ANGELL, supra note 6, at 106-08.

${ }_{182}$ Fish sometimes could be controlled, however, in particular, shore owners at the mouths of spawning streams could control an entire group of anadromous fish swimming upstream. Where legislatures gave these owners exclusive fishing rights-as occurred in some American states in the 18th and early 19th centuries-the owners controlled all the fish and presumably had some incentive to preserve the resource. Bennett v. Boggs, 3 F. Cas. 221 (C.C.D.N.J. 1830) (No. 1,319) (private rights in anadromous fish, particularly shad); see, e.g., Nickerson v. Brockett, 10 Mass. 212 (1813); see also Chalker v. Dickinson, 1 Conn. 382 (1815) (public may grant exclusive shad fishing right, though not proved here); Lund, Early American Wildlife Law, 51 N.Y.U. L. REv. 703, 717-19 (1976). For regulation of private fisheries, see infra text accompanying notes 205-06.

18s Perhaps the underlying theory of the older fishing-as-public-trust cases was that the fishermen might as well have the full benefit of fishing, without intervention of some landowner. Tober notes the anti-aristocratic flavor of early American attitudes to wildlife generally. The fishermen were doing the actual work, and the only known form of privatization-allocation to bank owners-merely transferred the product of their labor without preserving the resource. See J. ToBer, supra note 178, at 17-18, 20. The concern for rewarding the labor of the fisherman is reflected in Carson v. Blazer, 2 Binn. 475, 486-87 (Pa. 1810). This case, while rejecting the claim to an exclusive fishery extending to the middle of a large river, was clearly concerned about preserving the efforts of those who cleared out shad pools. 
early as $1876,{ }^{184}$ the Supreme Court held that a state could limit oyster bed planting and fishing to its own citizens. In more recent years, of course, fishing rights have been controlled by governmental bodies, which in principle-however hesitantly in practice-are more capable of managing the resource in a unitary form. ${ }^{185} \mathrm{De}$ spite this movement toward governmental "ownership," custom suggests that there may be a middle ground between regimes in which the resource is so plentiful or so difficult to privatize that it is not worth the effort, and regimes in which conflicting uses are managed by formal ownership. This middle ground is the regime of the managed commons, where usage as a commons is not tragic but rather capable of self-management by orderly and civilized people. ${ }^{188}$

The history of fishing provides another lesson. Inadequacies in a customarily managed commons might lead in one of two directions: toward ownership by individuals, as happened to commons used for grazing, wood gathering, and so forth; or toward government "ownership," as occurred to fishing, and now of course to roadways and waterways as well. Public trust doctrine, as well as certain aspects of the public prescription doctrines, ${ }^{187}$ suggested that certain property always went in the latter direction. Such "inherently public property" might initially "belong" to or be acquired by the public as a commons; but if informal, customary management failed, governments were obliged to assume and maintain public access against claims of exclusive private ownership.

\section{The Dangers of Privatization: Holdouts and Monopolies}

What was so bad about private ownership of "inherently public properties"? Governmental use of eminent domain suggests one answer. This power to force a sale at fair market price is typically

184 McCready v. Virginia, 94 U.S. 391 (1876). But see Hughes v. Oklahoma, 441 U.S. 322 (1979) (state prohibition on export of minnows violates interstate commerce clause), overruling Geer v. Connecticut, 161 U.S. 519 (1896) (state "owns" wildlife and may prohibit its export).

${ }^{183}$ For the development of state regulation in the 19th century, see J. TOBER, supra note 178, ch. 5; for an exhaustive account of one of the most advanced state regulatory systems, that of California, see A. McEvoy, supra note 175, chs. 5-10.

186 For an example of a similar expectation that the public will control itself, see Moose Free to Roam in their New Home, Chicago Tribune, March 26, 1985, § 1, at 6, col. 1 (public expected to "regulate itself" and not poach newly introduced moose).

${ }^{187}$ See, for example, doctrines in which the general public's use "accepts" a roadway, such that a governmental body is obliged to take responsibility for maintenance. See supra text accompanying notes 104-10. 
authorized where a government-sponsored project-such as a road-requires assembly of a number of pieces of land. If such projects had to rely on voluntary sales, any individual landowner might "hold out" for a prohibitively high price and block the entire project. Thus the eminent domain power has been justified as permitting acquisition of necessary private properties at a price reflecting fair market value, rather than the "rent" that each private owner might otherwise extract. ${ }^{188}$ The law of eminent domain often reflects this anti-holdout rationale by confining the power to situations where holdout is a genuine threat. Sometimes this is accomplished through statutory requirements that governmental bodies attempt negotiation before condemnation, ${ }^{189}$ yet more often it comes about through judicial decisions explicitly or implicitly requiring a "holdout" threat as a component of the "public use" prerequisite to eminent domain takings. ${ }^{190}$

Some nineteenth-century doctrinal controversies pointedly implied a similar anti-holdout rationale both for public prescription of roads and for public trust in waterways. But nineteenth-century case law also included some anomalous doctrines, whereby properties were presumed public even though monopoly or holdout potential seemed absent. Once again, doctrines of custom help to explain those anomalies, and in turn, the anomalies enrich our understanding of the road and waterway doctrines.

\section{A. Roadway Prescription and the Boundedness of Location}

One controversy of particular importance for nineteenthcentury roadway prescription concerned the location of purported roads. The older cases often held that the public could acquire prescriptive rights of passage in a narrow path, but not in open and uncultivated fields. ${ }^{191}$ On open fields, public passage was presumed

${ }^{188}$ See Berger, The Public Use Requirement in Eminent Domain, 57 Or. L. Rev. 203, 224-25 (1978) (holdout as justification for eminent domain, using evidence from condemnation for public utilities, irrigation, etc.); Calabresi \& Melamed, Property Rules, Liability Rules, and Inalienability: One View of the Cathedral, 85 HARv. L. REv. 1089, 1106-07 (1972); Meidinger, The "Public Uses" of Eminent Domain: History and Policy, 11 EnvTL. L. 1, 49 (1980); see also Merrill, The Limits of Eminent Domain: An Economic Analysis of "Public Use" (forthcoming); cf. Munch, An Economic Analysis of Eminent Domain, $84 \mathrm{~J}$. Poz. Écon. 473 (1976) (states the holdout rationale but argues that eminent domain is also inefficient).

${ }^{189}$ See 6 Julius Sackman, Nichols' The Law of Eminent Domain § 24.14 [1] (3d rev. ed. 1985).

190 See Merrill, supra note 188.

191 B. ElliotT \& W. ElliotT, supra note 49, § 176, at 189 (must be "well defined line"); id. $\S 164$, at 177 (presumption against dedication of uncultivated fields); see, e.g., Kyle v. 
to be by permission of the owner, and could give rise to no inference of dedication or adverse use.

Courts gave several reasons for this limitation. One was the magnitude of the owner's possible loss: if the public could acquire access or a right-of-way by going anywhere across a tract, an owner could be entirely divested of his property. ${ }^{102}$ This reasoning recognized that the private owner did indeed lose something by the public's prescription, and attempted to minimize the loss. Sometimes this rationale was stated as a wish to avoid the unneighborly acts that might follow if a landowner thought that his generosity would lead to a loss of property. ${ }^{193}$

However, other rationales contradicted this loss-minimization policy. For example, it was said that public passage across open and uncultivated fields would not support a prescriptive right because such public use did not preclude any use by the owner himself, and so was not genuinely adverse. ${ }^{194}$ Here too courts invoked a neighborliness rationale: if an owner was not hurt he should not be bound to undertake pointless, difficult, and unneighborly tasks to block public passage, such as fencing in or guarding remotely situated lands, simply for spite. ${ }^{195}$ In short, public prescription doctrine only deprived the owner of his rights if he really did lose something important from public crossings-that is, when the crossings occurred on enclosed and cultivated fields.

Town of Logan, 87 Ill. 64 (1877); City of Manhattan Beach v. Cortelyou, 10 Cal. 2d 653, 668, 76 P.2d 483, 490 (1938).

192 See, e.g., F.A. Hihn Co. v. City of Santa Cruz, 170 Cal. 436, 448, 150 P. 62,68 (1915) overruled sub silentio by O'Banion v. Borba, 32 Cal. 2d 145, 195 P.2d 10 (1948); see also Pearsall v. Post, 20 Wend. 111 (N.Y. 1838) (distinguishing public acquisition of roadway from public use of entire plot).

193 Pearsall, 20 Wend. at 135 (to allow public acquisition of an entire open space "would be perverting neighborhood forbearance and good nature," and cause a destruction of rights).

104 For a fairly recent application, see Sanchez v. Taylor, 377 F.2d 733 (10th Cir.1967); for earlier cases, see infra note 195.

${ }^{105}$ Kyle, 87 Ill. at 67 (no adverse inference from public's use of owner's open space; while so much land is held in common, the public is free to come and go until the owners have it fenced); Warren v. President of Jacksonville, 15 Ill. 236, 241 (1853) (same, where it was "neither the temper, disposition, fashion or habit of the people, or custom of the country" to prevent use). There was also an issue of the proportionality of effort in blocking access: if the public were only using a narrow path, an owner might easily "rebut" the presumption of dedication by blocking the pathway; and if he did not do so, he was in effect sleeping on his rights and perhaps deserved to lose them. But if public passages went any which way across open and uncultivated areas, it was much more difficult to block them, and to require owners to fence fields that were not even in use might cause needless expense, especially in remote places. See J. ANGell \& T. DurfeE, supra note 45, § 151 (effort to close roadways across woodlands would be ineffectual without constant watch). 
These reasons seem at best inconclusive. Open spaces could not be acquired by public prescription because the owner would lose too much to be fair to him-or contrariwise, because he would lose too little to presume genuine adversity. We must find other reasons for the narrow-passage rule; and the anti-holdout rationale is a very strong contender.

Insofar as the specific passage rule related to areas where much land was open and unused, the public had many potential pathways; hence there was little danger if one owner or another enclosed his land and blocked public crossing. Conversely, insofar as the rule permitted prescription of a narrow, defined path, it suggested that the public had singled out a particular passage that might be especially valuable. Without public prescription doctrine, each owner along the way might bar the passage at will and siphon off its public value, thus capturing the "rents" from that public usage. But this is precisely what the rule prevented.

As a general rule, then, the public could never acquire property by prescription; the exception for roadways applied only to specific passageways, not to open spaces. This exception prevented private holdout against public passage; but it only came into play upon a genuine threat of such behavior. Public meanderings anywhere across an open field suggested that the public had no focused need for a particular path and private owners felt no pronounced temptation for exploitation; therefore such meanderings would not raise a presumption of "dedication."

This anti-holdout rationale is strengthened by its similarity to other nineteenth-century American roadway doctrines. Roadways were the classic subject of eminent domain by the "organized" public. ${ }^{198}$ Prescriptive doctrines, by analogy to private law doctrines, assured that the "unorganized" public-which could not exercise eminent domain-was also protected from private holdout. A private party could sometimes own a toll road, but his potential power to capture all "rents" of travel was tempered by treatment as a public utility: the road was open to all members of the public, and the owner could charge tolls reflecting not what the market would bear, but only what would suffice to reimburse his expenses. ${ }^{187}$

106 Meidinger, supra note 188, at 13; 1 NicHoLs, supra note 189, § 1.22[1] (roadways the chief purpose of eminent domain).

197 See, e.g., Commonwealth v. Wilkinson, 33 Mass. (16 Pick.) 175, 177 (1834) (toll road is public for purposes of indictment against obstruction; makes no difference that it was not constructed initially at public expense but rather owner is reimbursed through toll); B. ElLI- 
The difficulty with the anti-holdout explanation is that the specific-path exception had its own exception: public squares. Squares were the exceptional open space that could be acquired by "implied dedication." squares for strolling, meetings, or soapbox speeches, open squares hardly seem comparable to the easily-monopolized road passage. If one owner refuses to let his property be used as a square, the public or its agents can move elsewhere without any special fear of "rent capture" through holdout or monopoly prices. President of Cincinnati v. Lessee of White, a Supreme Court case involving implied dedication of a square, raised the extortion point, but only obliquely: one may infer that the public has "accepted" a square's dedication, the Court said, if its use has lasted sufficiently long that the public would be "materially affected by an interruption of the enjoyment."199 But why should long use raise the possibility of extortion, if other spaces were available?

Some waterway cases may throw a little light on the issue raised by public squares, since recreation looms large in both areas. Indeed, despite the strength of the anti-holdout rationale in many waterway controversies, ${ }^{200}$ recreational use challenged that rationale, just as the exception for squares challenged it in the roadway cases.

\section{B. Navigable Waterways and the Recreation Controversy}

Like roadway doctrine, waterway doctrine also reflected an antipathy to the possibility of private monopolization of public passage. This was hardly surprising; it was a commonplace of nineteenth-century jurisprudence that waterways were a "highway" for travel and commerce. ${ }^{201}$ Moreover, their location was

OTT \& W. ELLIoTT, supra note $49, \S 88$, at 99 (legislature may reasonably regulate tolls, though may not reduce toll below rate that will allow owner to maintain and make reasonable return on investment); see also Louis Hartz, Economic Policy and Democratic Thought: Pennsylvania, 1776-1860, at 159-60 (1948) (pre-civil war rate regulation, geared to return on investment).

108 See, e.g., President of Cincinnati v. Lessee of White, 31 U.S. (6 Pet.) 431 (1832); Pearsall, 20 Wend. at 117-19; Trustees of Methodist Episcopal Church v. Mayor of Hoboken, 33 N.J.L. 13, 22 (1868) (park may be accepted by public use); see also Hoadley v. City of San Francisco, 50 Cal. 265, 275 (1875); Commonwealth v. Alburger, 1 Whart. 469 (Pa. 1836) (squares can be dedicated).

${ }^{109} 31$ U.S. (6 Pet.) 431, 439 (1832).

200 See infra text accompanying note 238.

${ }^{201}$ See, for example, the well-known case of Carson v. Blazer, 2 Binn. 475,485 (Pa. 1810) (state legislature had declared the Susquehanna River a "highway"). See also Westonk, Public Rights in Pennsylvania Waters, 49 TEMP. L.Q. 515, 531 (1976) (longstanding 
largely fixed by nature, so that their use was even more subject to holdout than roadways, which are movable. Thus holdout potential explains several cases elevating the public right of water passage above all other uses, even bridges for land roads unless specifically authorized by legislatures. ${ }^{202}$ Land traffic might find some other route, whereas ships had no alternative and were especially susceptible to exploitation.

But the most interesting controversy on the holdout issue concerned the question of whether recreational uses might support a right of public access to waterways and their shores. This issue in turn is curiously related to the question of whether fishing is a public trust purpose. Fishing is of course not necessarily or even primarily a recreational use; but as it became assimilated to sporting and recreation in the later nineteenth century, fishing-as well as hunting-increasingly acquired the attributes of a public trust purpose. ${ }^{203}$

Putting to one side other arguments for (or against) public fishing rights, ${ }^{204}$ the holdout argument seems thin. Even in those states where riparian owners controlled fishing rights, ${ }^{205}$ they could always sell the right of access; unless one or a few owners held the entire shore or riverbank, none could monopolize fishing. Where special circumstances permitted private monopolization of fishing, as at the mouth of a spawning stream for anadromous fish, early nineteenth-century law granted private property rights but obviated the monopoly problem by treating the fishery as a public utility $^{206}$-with obvious analogies to private toll roads. ${ }^{207}$ The poten-

use of term "public highway" to refer to navigable waters).

${ }^{202}$ Commonwealth v. Inhabitants of Charleston, 18 Mass (1 Pick.) 180, 187-88 (1822) (bridge/waterway conflict; waterways are highways, especially required to be open to the public); see, e.g., Inhabitants of Arundel v. M'Culloch, 10 Mass. 70 (1813) (waterway use superior to bridge).

${ }^{203} 1$ ClARK ON WATER RIGHTS, supra note 64, § 36.4(B), at 201; State ex rel. Thompson v. Parker, 132 Ark. 316, 324-25, 200 S.W. 1014, 1017 (1917) (hunting and fishing on navigable waters is a public right); Ainsworth v. Munoskong Hunting and Fishing Club, 153 Mich. 185, 190-91, 116 N.W. 992, 993 (1908) (same, is for "recreation and health"); Diana Shooting Club v. Husting, 156 Wis. 261, 271-72, 145 N.W. 816, 820 (1914) (fishing and hunting are mainly recreational activities, navigable waters open to them and other recreation).

${ }^{204}$ See supra text accompanying notes 175-83.

${ }^{203}$ Compare, e.g., Schulte v. Warren, 218 Ill. 108, 119-21, 75 N.E. 783, 785-86 (1905) (the public has no right to fish in all navigable waters, but only those owned by the state; fish belong to the owner of the underlying soil), with Collins v. Gerhardt, 237 Mich. 38, 48, 211 N.W. 115, 118 (1926) (fishing is a part of the public trust in navigable waters, without regard to underlying owmership of the soil).

${ }^{206}$ See Lund, supra note 182, at 718. Some British cases also concerned situations in which monopoly was a possibility, for example, riparian owners on "arms of the sea," who could block the passage of ocean fish upstream or downstream in tidal waters. In these 
tial for holdout seems even more doubtful in the case of hunting, since wild animals roam all over; yet some later cases nevertheless designated hunting a public trust right. ${ }^{208}$

This minimal danger of monopolization may explain why fishing historically has been weaker than commerce as a "public right" on navigable waterways, and why private fishing rights often existed even in navigable waters, as well as why hunting was often overlooked as a public trust purpose. ${ }^{209}$ But this must whet our curiosity as to why fishing was ever described as jus publicum, and why fishing and sometimes hunting were increasingly deemed public rights as these activities acquired greater recreational connotations. The question is equally puzzling in the case of more general recreational uses. The early rule denied that recreation was a trust purpose; but by the later nineteenth century a number of American jurisdictions recanted and held that recreation would support public use of navigable waterways. Here too, questions of monopoly were thought relevant, and contemporary courts dealing with recreation claims occasionally glanced at least briefly at such issues.

A leading precedent against public rights to waterfront recreation was an 1821 British case, Blundell v. Catterall, ${ }^{210}$ which presented one of the more peculiar fact situations in land use law. It concerned a claim that the public had the right not only to use shorelands for swimming, but also to bring horse-drawn "bathing machines" across the beach for that purpose. ${ }^{211}$ Blundell's majority

cases, the public was presumed to have a right to fish, but a private owner could rebut the presumption and claim ownership rights if he could show a specific grant or prescriptive right. See Carter v. Murcot, 4 Burrow's Rep. 2162, 2164, 98 Eng. Rep. 127, 128-29 (K.B. 1768) (private fishing rights in arm of sea had to be proved).

207 See supra text accompanying note 197.

208 See supra note 203. Obviously, one can fish only in a river or a body of water, but (aside from waterfowl hunting) one can hunt in a variety of places. Thus fishing might conceivably be monopolized by the owners of the submerged land-more than hunting, though certainly not so much as travel and commerce might be. But see Ainsworth, 153 Mich. at 192 (equating hunting with fishing); Diana Shooting Club, 156 Wis. at 269 (same).

${ }^{202}$ See, e.g., Harrison v. Fite, 148 F. 781, 784 (8th Cir. 1906) (use of waterway for hunting and fishing from skiffs or small boats does not make waterway navigable and therefore public); Diana Shooting Club, 156 Wis. at 271 (hunting and fishing are subordinate to commerce and navigation). For other reasons why fishing may have been a secondary "public trust" purpose, see notes $181-89$ and accompanying text.

${ }^{210} 5$ B. \& Ald. 268, 106 Eng. Rep. 1190 (K.B. 1821). For the importance of the case, see 1 R. ClarK, supra note 64, § 36.4(B), at 201; cf. Comment, Waters and Watercourses-Right of Public Passage Along Great Lakes Beaches, 31 Mrch. L. Rev. 1134, 113637 (1933) (critical discussion of Blundell).

211 The author has sought in vain for an illustration of a "bathing machine," and can only say that these devices seem to have had something to do with preserving the modesty 
opinions distinguished recreational beach uses from the historic public rights of navigation and fishing, and focused chiefly on the excessive limitations and irritations that would burden waterfront owners if such wide-ranging public access were upheld. ${ }^{212}$ Having fishermen and commercial vessels pass by was one thing, but having one's waterfront improvements curtailed, or having to put up with naked youths splashing about-or even modest ladies and gentlemen in "bathing machines"-was quite another. ${ }^{213}$ The public right to use the seashore was thus held to exclude these recreational pursuits.

Justice Best dissented. Although he has been described as an "old fashioned judge,"214 his opinion has a curiously up-to-date flavor-indeed, it strikingly presages the modern arguments in favor of recreation as a trust purpose. He argued that the shore has always been impressed with a public trust, ${ }^{215}$ that "universal custom" supports recreational use of the beach, ${ }^{216}$ that bathing is important and indeed necessary for the public health, ${ }^{\mathbf{2 1 7}}$ and that bathing is not really different from navigation. ${ }^{218}$ Best even argued that bathing aided navigation: swimmers learn to feel at home in the water, and thus can assist sailors in distress. ${ }^{219}$ One of Best's arguments obliquely raised holdout issues: if private owners had exclusive control of the beach, they could thwart the public's use for no good reason, excepting only "the hateful privilege of vexing their neighbours."220 This of course presumed monopoly: that would-be swimmers could find no shore owner willing to bargain

of the swimmers. Blundell, 5 B. \& Ald. at 306, 106 Eng. Rep. at 1204 (Bayley, J.) (discussing "machines" in the context of "decency," privacy, and the separation of men's and women's machines). Two colleagues, Mark Grady at Northwestern University and Richard Helmholz at the University of Chicago, claim to have seen illustrations of "bathing machines," the latter stating that the machines resembled horse-drawn outhouses. My editor advises that she has seen a bathing machine in the 1939 motion picture, "The Ghost and Mrs. Muir," starring Rex Harrison and Gene Tierney.

${ }_{212}$ Id. at 294, 299, 106 Eng. Rep. at 1199-1200, 1201 (Holroyd, J.); id. at 304, 306, 310, 106 Eng. Rep. at 1203, 1204, 1205 (Bayley, J.); id. at 313-14, 106 Eng. Rep. at 1206 (Abbott, C.J.).

${ }^{213}$ Id. at 305-06, 310, 106 Eng. Rep. at 1203-04, 1205 (Bayley, J.); id. at 313-14, 106 Eng. Rep. at 1206 (Abbott, J.).

214 P.S. Atryah, The Rise and Fall of Freedom of Contract 169 (1979).

215 Blundell, 5 B. \& Ald. at 287, 106 Eng. Rep. at 1197 (Best, J., dissenting).

${ }^{216}$ Id. at 278, 280, 106 Eng. Rep. at 1194, 1195.

217 Id.

218 Id. at 280,106 Eng. Rep. at 1195.

218 Id. at 278-79, 106 Eng. Rep. at 1194.

${ }^{220} I d$, at 287,106 Eng. Rep. at 1197. Judge Best's comment was recently quoted with approval by the New Jersey Supreme Court in Matthews v. Bay Head Improvement Ass'n, 95 N.J. 306, 324, 471 A.2d 355, 364-65 (1984). 
with them for permission to swim.

Perhaps other judges of the period simply disbelieved this; Justice Best's colleagues seemed unconvinced. ${ }^{221}$ Beach recreation had then come into vogue relatively recently, ${ }^{222}$ and even then, it hardly seemed that recreational use of waters could be monopolized as navigational uses might be. Indeed, shore owners were quite willing to enter into commercial arrangements for other people's recreational use. ${ }^{223}$ After Blundell, which was much cited in America, ${ }^{224}$ the standard position until late in the century was that recreation was not a trust purpose that would support public use of waterways or adjacent riparian tidelands.

This rejection of recreation as a public trust purpose, taken together with strong protection of commercial travel on waterways, suggests that the fear of private holdout was central to early nineteenth-century thinking about public access to waterways. Later the disfavor to recreational uses eroded, ${ }^{225}$ but courts still attempted to use a holdout argument. One case recognizing recreation as a trust use was Guilliams $v$. Beaver Lake Club; ${ }^{226}$ it was by no means the first in this trend, but it defended recreation in an interesting way. The court assimilated recreational uses to commerce and travel over roadways, saying the waterways had become "valuable highways," and that a vessel using the waterway to carry picnickers to a beach was just as much engaged in commerce as a boat carrying grain or merchandise. ${ }^{227}$

This rationale, however, hardly applied to swimmers staying in one place. The uses of waterways most subject to monopolization

2215 B. \& Ald. at 315, 316, 106 Eng. Rep. at 1207 (Chief Justice Abbott mentioned the commercialization of beach recreation and the apparent willingness of waterfront owners to participate).

${ }_{232}$ The Public and the Foreshore, 139 The Times (London) 381, 383 (1915) (bathing has been in fashion only since the late 18th century in England).

223 See supra note 221.

224 Nolan v. Rockaway Park Improvement Co., 28 N.Y.S. 102, 103 (N.Y. Sup. Ct. 1894) (owner can exclude member of public from private beach recreation facility, citing Blundell); see, e.g., Henry Farnham, The Law of Waters and Water Rights $\S 46$, at 232 n.19 (1904) (Blundell cited as authority that public rights to navigable waters exclude recreation); see also 1 R. CLARK, supra note $64, \S 36.4(\mathrm{~b})$, at 201.

${ }_{225}$ See, e.g., Attorney Gen. v. Woods, 108 Mass. 436, 440 (1871) (enjoining damming of a stream, even though it was used only by pleasure boats, not commercial boats); Lamprey v. State, 52 Minn. 181, 198-200, 53 N.W. 1139, 1143-44 (1893) (dicta) (lakes are held by the state in public trust if used for any "beneficial" purpose, whether pleasure or commercial).

22890 Or. 13, 175 P. 437 (1918).

222 Id. at 27,175 P. at 441 . A similar suggestion was made earlier in Woods, 108 Mass. at 439-40, where it was said that "[n]avigable streams are highways; and a traveller for pleasure is as fully entitled to protection . . . as a traveller for business" (emphasis added). 
or holdout were transportation and commerce, which involved movement from place to place over a relatively narrow "path.",228 As one British court stated, the beach is "not to be regarded as in the full sense of the word a highway," open to recreational uses: no matter how ungenerous the act, beach owners were entitled to treat as trespassers "every bather, every nursemaid with a perambulator, every boy riding a donkey, and every preacher on the shore."229

Thus, it is difficult to fit into a "holdout" rationale such public trust uses as swimming, fishing, and hunting. Recreational uses might occur in numerous places, without requiring any great stretch of waterway; moreover, in any normal market, a variety of riparian owners might compete to provide swimming or other recreational facilities. This presents the same problem as implied dedications of squares: why should we guarantee public access for recreational purposes when there seems to be no threat of private holdout?

\section{Customary Claims: Was There a Holdout Problem?}

Nineteenth-century English courts relied on custom to support a wide variety of claims to use land, ${ }^{230}$ and among these the most notable were recreational uses, where the holdout problem was less evident than with roads and waterways. Britons claimed customary rights to use otherwise private property for such purposes as horse races, dances, and cricket matches. ${ }^{231}$ Even the hapless "bathing machine" users in Blundell might have fared better

228 Length and narrowness may also be incorporated into the definition of "navigability," which in turn determines which waterways are subject to a right of public access. See, e.g., Lakeside Park Co. v. Forsmark, 396 Pa. 389, 392, 153 A.2d 486, 487 (1959) (defining as navigable a "long thin roadway of water joining regions and communities" rather than a merely local body of water); see also id. at 396, 153 A.2d at 489 (distinguishing a trade route from a "point of interest").

${ }^{229}$ Llandudno Urban Dist. Council v. Woods, 2 Ch. 705, 709, [1899] All E.R. 895, 896, 81 L.T.R. 170, 171 (1899).

${ }^{230}$ See supra text accompanying notes 138-43.

${ }^{231}$ Hall v. Nottinghan, 33 L.T.R. 697 (Ex. D. 1876) (customary right to hold maypole dance and other recreation on owmer's land); Mounsey v. Ismay, 1 Hurl. \& Colt. 729, 158 Eng. Rep. 1077 (Q.B. 1863) (customary right, "from time whereof the memory of man runneth not to the contrary," to hold annual horserace on owner's land); Fitch v. Rawling, $2 \mathrm{H}$. Black 393, 126 Eng. Rep. 614 (K.B. 1795) (customary right to play cricket on owner's land); Abbot v. Weekly, 1 Lev. 176 (17 Car. II), 83 Eng. Rep. 357 (K.B. 1665) (customary right to dance on owner's land upheld; continued to be cited into 19th century); cf. Bell v. Wardell, Willes Common Pleas Rep. 202, 207, 125 Eng. Rep. 1131, 1134 (1740) (custom to use owner's land for riding and strolling held bad, because unreasonable at time when crops were growing). 
had they pleaded a local customary right..32

If custom is indeed the medium through which a seemingly "unorganized" public may organize itself and act, ${ }^{233}$ and even "speak" with the force of law, ${ }^{234}$ this may suggest why squares or recreational areas were subject to holdout problems. One might be doubtful that customary recreational uses would require particular spaces in the way that roads or paths did: arguably people could hold a maypole dance anywhere. This reasoning, however, is insufficiently attentive to precisely the customary nature of the activities: over time, communities may develop strong emotional attachments to certain places, and to holding particular events in those places. ${ }^{236}$ To my fellow Chicagoans, I ask rhetorically: does it matter that the Cubs play in Wrigley Field? To Detroit residents, does it matter that the Tigers play in Tiger Stadium ${ }^{236}$ In general, the sense of the proper place for a given community activity may become fixed over time.

Thus the location of customary public activities may matter a great deal, not because it would be impossible to conduct these activities elsewhere, but because to relocate would rupture the continuity of the community's experience and diminish the significance of the activity itself. The community's custom signals its emotional investment in a place. Moreover, the custom communicates this information to everyone-including the property's owner who, under British customary law, acquiesced in that investment. ${ }^{237}$ If one thinks of a custom as a community investment, the danger of holdout seems much clearer. This may have motivated the Supreme Court's comment in President of Cincinnati v. Lessee of White that land "dedicated" to the public could be "accepted" by sheer public usage, if that use had continued so long that public

2325 B. \& Ald. at 289, 106 Eng. Rep. at 1198 (opinion of Holroyd, J.) (noting that that case was not pleaded on custom and does not affect customary claims); see also Llandudno Urban Dist. Council, 2 Ch. at 709, [1899] All E.R. at 896, 81 L.T.R. at 171 (right to recreational use of beach may be based on custom, but must be proved).

${ }^{233}$ See supra text accompanying notes 152-53.

234 1 W. BLACKSTONE, supra note 1 , at *67 (custom of the country is the common law). For a discussion of the analogy of custom to language, see J.H. BRowNE, THE LAW OF UsAgES AND Customs 17-18 (1875).

${ }^{230}$ Cf. Kevin Lynch, The Image of THE City 125-28 (1960) (associating individual sense of emotional orientation with memories of activities in particular physical locations).

${ }^{238}$ See Logan, A Timeless City Beauty: Wrigley Field's Tradition Spans Generations, Chicago Tribune, June 28, 1985, $\$$ 4, at 1, col. 2; Logan, Tiger Stadium: Detroit's Anchor, Chicago Tribune, June 27, 1985, § 4, at 1, col. 3 (describing Tiger Stadium as a "unifying force for a fragmented city").

${ }^{237}$ One of the requirements of a customary right was that it must have been undisputed over a long period of time. See supra note 140 . 
"accommodation" would be substantially affected by interruption. ${ }^{238}$ It was the public's habit of use, rather than anything unique about the property ab initio, that made the property subject to private rent-seeking.

Thus habit, expectation, custom, perhaps tied to a variety of community practices, may make a property hostage to private "holdout" power. The public's custom of dancing and carousing in a particular place, like its habit of traveling on certain paths, makes these various lands essential. Returning to the recreational uses of waters, perhaps the custom of using particular places for recreation eventually led courts to find that these uses were uniquely valuable to the public: the old swimming hole or fishing spot might be especially vulnerable to rent-seeking behavior. ${ }^{239}$

But are roads and waterways really different from customary recreational uses? By long usage, the public singled out and chose the roadways that became subject to prescription. ${ }^{240}$ In a still deeper sense, these travel and transport spaces are valuable because we are in the custom of trading, and in general have the customs of a commercial people, for whom ever-expanding markets are particularly important. By these customs, the general public communicates to everyone the high value that it places on roads and waterways, just as the smaller locality signals its value of the maypole field. ${ }^{241}$ Where that signaling has gone on for sufficient time without interruption, the public's "investment" grows higher and may tempt the owner to hold out; to prevent this, the law shifts the presumption to favor the public's use over the private owner's right to exclude.

Custom thus explains why holdout problems might affect recreational property. Indeed it goes further and deepens our understanding about the holdout problem for roads and waterways as

$2 s 831$ U.S. (6 Pet.) 429, 439 (1832).

${ }^{239}$ This seems to have been the thinking of Judge Best, the dissenter in Blundell, in defending recreational beach use as a customary right, $5 \mathrm{~B}$. \& Ald. at 278, 280, 106 Eng. Rep. at 1194, 1195, and one which the private owner might remove for no productive purpose, id. at 287, 106 Eng. Rep. at 1197. See supra text accompanying note 220. This argument would not hold for all recreational uses, only for those that had continued on a given property over a long period of time: the time-honored "old swimming hole," but not the new beach cabana.

${ }^{240}$ This use or singling out of a particular way is reflected in the narrow-path rule for public prescription of roadways; see supra text following note 195.

${ }^{241}$ For the general public's communication of its needs, see, e.g., City of Visalia v. Jacob, 65 Cal. 434, 436 (1884) (governmental body cannot sell or lose by adverse possession a roadway, which it holds "in trust" for the public, so long as the public is continuing to use it as a roadway); Manderschid v. City of Dubuque, 29 Iowa 73, 85 (1870) (governmental body has duty to maintain road when public use has demonstrated public need). 
well: these properties are especially important to a society with the habits of commerce, like our own.

But even if the holdout danger was necessary for a presumption of "publicness," that danger cannot have been sufficient. Surely, there should also be some reason to suppose that a property will be more valuable if open to public access than it would be under exclusive private control. ${ }^{242}$ We know from eminent domain law that many properties are unique and thus vulnerable to holdout; yet some of these are nevertheless unsuitable for public appropriation, because the public body is not willing to pay even fair market value for them. Unlike eminent domain, public prescription and public trust doctrines require no payment to the owner; thus they never make even this simple test of relative value. How, then, can we know whether such property will be more valuable in public hands?

\section{What Was the Value of the Public Use? Open-endedness, NEgOTIATIONS, INTERACTIONS}

One place to look for answers to the relative value problem is in the police power exercised by the "organized" public, because this power also entails uncompensated public controls over otherwise private property. Frank Michelman's well-known formulation of the Benthamite "felicific calculus" explains this on efficiency grounds. No compensation is paid when the costs of arranging payment are too high, or more specifically, when the "demoralization costs" of non-payment to the owner are outweighed by the "settlement costs" of administering and paying compensation. ${ }^{248}$

An echo of this formulation exists in public prescription and public trust doctrines. Earlier sections described some doctrines that attempted to minimize "demoralization costs," stricting public access in order to preserve the owner's property, as in the narrow passage limitation, ${ }^{245}$ or in the common law prohibitions against public abuse of roads or waterways. ${ }^{248}$ Moreover, the public's use was normally limited to an easement rather than to a

242 See, e.g., Calabresi \& Melamed, supra note 188, at 1106-07 (use of eminent domain to overcome holdout presumes that property taken is more valuable for governmental purpose than in hands of former owners).

26s Michelman, Property, Utility and Fairness: Comments on the Ethical Foundations of "Just Compensation" Law, 80 HaRv. L. REv. 1165, 1214-15 (1967).

244 See supra text accompanying notes 191-92.

${ }^{245}$ See supra text accompanying notes 164-66.

${ }^{248}$ See supra note 47 (prescriptive right of way an easement), note 181 (public easement over privately owned streambed). 
fee interest: thus it only partly divested private ownership and was deemed compatible with a private owner's continued title to the roadway land or land submerged beneath waterways. ${ }^{247}$ One sees the same efforts in customary doctrines, where "usufructory" public rights were denied because they would be too damaging to the fee owner. ${ }^{248}$

Public prescription and trust doctrines also fit the other side of Michelman's equation-the high costs of negotiating a compensated settlement-although the settlement cost rationale does not completely solve the relative value problem.

\section{A. Settlement Costs and Open-ended Access: The Roadway Cases}

Traditional roadway doctrines drew several distinctions that effectively limited public prescription to properties that were subject to high settlement or negotiation costs. One important doctrine held that before property could be claimed as "public," its users had to comprise an indefinite and open-ended class of persons: as one court said, the road had to be open to "strangers." Indeed, a routine ground for denying that a street or road had become public by long usage was that the purported "public" were specific persons rather than anyone who simply happened along. ${ }^{250}$ This is still true; if the roadway users are the same few persons, arguably the road is not really "public," and their use will give rise at most to private prescription, benefiting only them. ${ }^{251}$

This issue arose chiefly in cases about cul-de-sacs or roadways ending in particular locations. Cul-de-sacs are used chiefly by a small, identified group, but those persons may be visited by anyone at all: not surprisingly, they caused considerable pondering among nineteenth-century roadway jurisprudes. Some experts viewed

247 See generally Livingston, supra note 15 , at $688-98$ (burden to private owner an important factor in implied public dedication/prescription).

${ }^{248}$ See supra note 154; see also supra notes 157-58 and accompanying text (customary rights had to be "reasonable").

${ }^{249}$ Rung v. Shoneberger, 2 Watts 23, 25-26 (Pa. 1833) (language about "strangers"; although the case concerned obstruction of a square, the court likened squares to streets); see also People v. Kerr, 27 N.Y. 188, 192, 198-99 (1863) (public trust over streets if for benefit of the "whole people," not just adjacent owners or inhabitants of the city).

${ }^{230}$ See, e.g., Simmons v. Mumford, 2 R.I. 172, 183-84 (1852) (street leading to private property is not "dedicated" to the public).

${ }^{251}$ See, e.g., Smith v. Thomas Elevator Co., 278 Ill. 328, 116 N.E. 113 (1917); Batchelder Co. v. Gustafson, 32 Ill. App. 3d 14, 335 N.E.2d 565 (1975); Rominger v. City Realty Co., 324 S.W.2d 806 (Ky. 1959); see also Livingston, supra note 15, at 689-90 (small number of persons cannot establish right for public at large because that would be too burdensome on the owner). 
them as genuine roadways, but others, particularly in Britain, thought cul-de-sacs did not count as "public." They thought the public could acquire a roadway through usage only if it were a throughway; ${ }^{252}$ a road was not public if it just stopped somewhere. In the United States, another refinement was added: roads that ended at some other transportation terminal (such as a ferry) counted as "roads" for purposes of public prescriptive acquisition. ${ }^{253}$

The doctrine requiring open-ended use makes some sense from a perspective of negotiation or settlement costs. If a few specific persons use a roadway, they can locate each other and negotiate together with the owner to transfer a right of passage; ${ }^{254}$ if they do not, presumably they value the right of passage less than the owner values the right to exclude them. The more people, and the less specific their identities, the less likely it becomes that they can afford the costs of arranging a consensual bargain. ${ }^{255}$ Moreover, the more persons involved, the greater the likelihood that road users collectively will value the right of passage more highly than the owner values his right to exclude-but the greater the difficulty of acting on those respective valuations.

On the other hand, the number of persons was not the only factor or necessarily the crucial one. As noted earlier, the older doctrines sometimes made roadways public even though the users were few and their use unintensive-so long as their identity was indefinite. ${ }^{256}$ This too might be consistent with a settlement cost analysis, in view of the asymmetry between the respective positions of the owner and the "public." The members of an indefinite group-even though small-might be unable to demonstrate their interest in a pathway, since they would have to find each other and arrange a bargain. The owner, on the other hand, could protect his interest relatively easily, and could rebut any presumption of "dedication" by a variety of acts, such as putting up a fence or plowing up the passageway. ${ }^{257}$ These acts might well be simpler for

232 J. ANGELL \& T. DURFEE, supra note 45, §§ 136-37.

253 Id. at $\$ 138$.

2st For an excellent and succinct statement of this view, see Merrill, Trespass, Nuisance, and the Costs of Determining Property Rights, 14 J. Legal Stud. 13, $21-22$ (1985).

${ }^{235} I d$. at 26-35 (describing problem in context of nuisance law); see also Calabresi \& Melamed, supra note 188, at 1107 (eminent domain may be appropriate where large number of users creates difficulty in assessing individual use).

${ }^{256}$ See supra text accompanying notes $98-100$.

${ }_{257}$ See B. ElliotT \& W. ElliotT, supra note 49, § 166, at 178-79; see also Smith v. Thomas Elevator Co., 278 Ill. 328, 116 N.E. 113 (1917) (owner put up signs); Livingston, supra note 15 , at 703.04 (passive landowner presumed to be indifferent). 
him to perform than it would be for the transient and nonspecific users to find and transact with each other and him. Thus, if the owner failed to take such steps, the legal doctrines presumed that he did not value his property very highly, and in effect had "given" it to the unidentified users.

But this only complicates the problem of relative value. We might concede that it is difficult for indefinite "strangers" to negotiate with each other and with the owner; but if their overall numbers were small, and their use of the property merely casual, those facts would much weaken any presumption that their use was more valuable than the private owner's. Why then did indefiniteness of use-abstracted from numbers or intensity of use-count as the essential measure of "publicness"?

\section{B. Waterways and the Definition of "Navigable"}

When we turn to waterways, we find the same insistence on indefiniteness of the number and identity of users. But unlike the roadway cases, the cases regarding waterways and submerged lands seldom stated this requirement explicitly. The criterion was implicit, however, in the limitation of the public trust to "navigable" waters and lands underlying them.

"Navigable" has been variously defined. ${ }^{268}$ "Navigable waters" are sometimes said to include only waters capable of carrying commercial vessels; ;59 more generous definitions included turbulent streams if they could float logs to market ${ }^{260}$ or, more recently, waters usable by recreational vessels even as small as canoes. ${ }^{261}$ However, the classic measure of navigability is suitability for commerce, however defined; ${ }^{262}$ and commercial use suggests an

${ }^{2 s 8}$ For an exhaustive discussion of the various American definitions, see MacGrady, supra note 9, at 587-605. As MacGrady points out, there are similar though slightly different definitions for purposes of determining federal admiralty jurisdiction, federal regulatory authority, and-most important for "public trust" doctrine-subsoil ownership; and with respect to the last subject, the definitions further subdivide into state and federal. Id. at 58788.

${ }^{259}$ E.g., The Daniel Ball, 77 U.S. 557, 563 (1870) (admiralty definition of navigable waters as those used, or capable of being used, "as highways for commerce").

280 See, e.g., Moore v. Sanborne, 2 Mich. 520 (1853).

${ }^{261}$ See, e.g., Lamprey v. State, 52 Minn. 181, 53 N.W. 1139 (1893).

${ }^{262}$ Definitions beyond "floating commercial vessels" still involved commercial enterprises. Log floating, for example, was clearly a substantial commercial enterprise: the Moore case concerned an obstruction of 10-15,000 logs, and the court noted their commercial importance. 2 Mich. at 522, 524, 526, 528. Even jurisdictions using the pleasureboat test sometimes analogized pleasureboat use to commercial uses. See supra text accompanying note 227. 
indefinite and open-ended set of individuals who use the waterway. All these definitions require that the waterway have a considerable extent: none would define as "navigable" a waterway that is confined within the ownership of one or a few landowners. ${ }^{263}$ Like a cul-de-sac, a small body of water generally has a few identifiable users (who presumably can adjust their respective rights by negotiation), and is distinguishable from a "long thin roadway of water joining regions and communities." 264

Thus only those waters that are potentially open to indefinite numbers of "strangers" count as navigable and hence subject to a public trust. Nevertheless, as in the roadway cases, the waterway definitions of "publicness" focused on the public as an open-ended class, rather than on the large numbers of users or the intensity of their use. This was most obvious when courts upheld navigation over all other waterway uses-no matter how intensive or valuable by comparison. When a Massachusetts court ruled that the public's right to use an inlet was superior to a bridge that obstructed it, it specifically found irrelevant the points that few boats used the inlet, that there was little settlement along its banks, and that the bridge had greater public utility. ${ }^{265}$ When a Wisconsin court halted an agricultural drainage project because it would impede boaters from reaching their accustomed fishing sloughs, the court paid little heed to the respective values of the competing uses. ${ }^{266}$

Taken together with the possibility of holdout by private owners, an open-ended class of users and the attendant negotiating difficulties seem to present the classic case for governmental acquisition at fair market value, through purchase or eminent domain. ${ }^{267}$

${ }^{263}$ See, e.g., Conneaut Lake Ice Co. v. Quigley, 225 Pa. 605, 610, 74 A. 648, 650 (1909) (dicta distinguishing navigable stream from small waterbody, where no reason for public to assert interest).

${ }^{204}$ Lakeside Park Co. v. Forsmark, 396 Pa. 389, 392, 153 A.2d 486, 487 (1959).

${ }^{205}$ Commonwealth v. Inhabitants of Charlestown, 18 Mass. (1 Pick.) 180, 187-88 (1822) (only the legislature could authorize the obstruction of the public's right to pass in the waterway); see also Inhabitants of Arundel v. M'Culloch, 10 Mass. 70 (1813) (upholding removal of bridge that obstructed inlet).

260 In re Crawford County Levee \& Drainage Dist. No. 1, 182 Wis. 404, 415, 196 N.W. 874,878 , cert. denied, 264 U.S. 598 (1924) (navigable waters cannot be filled, despite drainage commission's findings of compensating public benefits; the court did note, however, that many sloughs had already been filled).

${ }^{267}$ See Calabresi \& Melamed, supra note 188, at 1106-07 (negotiation problems of potential holdout by seller, or inability to assess costs to users, may justify eminent domain). Some modern public choice literature, however, casts doubt on the correspondence between governmental decisions and the preferences of the citizenry, particularly where governmental decisions intervene in normal market choices and create opportunities for rent-seeking payoffs to governmental decisionmakers. Buchanan, Rent Seeking and Profit Seeking, in J. 
But the analogy to eminent domain power once again raises doubts about public prescription or public trust in roads and waterways. The rationale of negotiation costs in some ways only begs the question: the "unorganized" public is always incapable of negotiating, precisely because it is unorganized. How can we surmise that this public's use is more valuable than that of private owners, when no exchange is bargained for, no payment made?

There are, after all, strong reasons for not favoring publicness. Unlimited access, by unidentified users, creates precisely the problem that theorists regard as the bane of publicness: no one minds the property, because no one has a specific interest in doing $\mathbf{s o}^{268}$ To be sure, customary practices may "govern" even an unorganized public, so as to manage common property in a rudimentary way; and the doctrines of inherently public property tended to attach to properties that were capable of such customary selfmanagement. ${ }^{268}$ But these doctrines never required the public -organized or unorganized - to purchase its rights of access; and this is precisely why we may doubt that the public's use is more valuable than a competing private use. Indeed, even where the organized public purchased through eminent domain, paying fair market value, we might still wonder why the public use should be presumed more valuable than the private use of an owner who is unwilling to sell at that price.

Nineteenth-century police power doctrine suggested a different rationale for this presumption. It suggested that an expansive, open-ended use might enhance, rather than detract from, the value of certain kinds of property.

\section{Scale Returns, Custom, Interaction}

At the turn of the century, police powers were commonly analogized to the powers of eminent domain. Enterprises that could be given eminent domain powers were thought to be the same as those subject to police power regulation. ${ }^{270}$ Moreover, rate regulation itself seems analogous to eminent domain: the public, through regulated rates, could purchase goods at fair market value rather

Buchanan, R. Tollison \& G. Tullock, Toward a Theory of the Rent Seeking Society 3, 10-12 (1980).

${ }^{288}$ See supra text accompanying notes 7-8.

${ }^{268}$ See supra text accompanying notes 162-70.

${ }^{270}$ Scheiber, supra note 42 , at $366-68$ (eminent domain powers given for public purposes, which in turn justified regulation). 
than at the higher rates the producers would otherwise charge. ${ }^{271}$ The enterprises subject to such regulation, according to nineteenth-century theory, were the "natural monopolies": those with increasing returns to scale, where greater production led to proportionally lower costs per item. According to Henry Carter Adams, such industries could not be governed by competition, since they could temporarily lower their charges and drive out competitors. ${ }^{272}$ In a sense, Adams implied that they were "naturally public"; either they could be publicly owned, or they could be privately owned but subject to a "public trust" regulation of their rates, such that the entrepreneurs received a fair return, but that the benefits of scale economies redounded to the consumers. ${ }^{273}$

One can find analogies to scale returns in the doctrines of "inherently public property," but this is more evident in the customary doctrines than in the doctrines relating to roads and waterways. The British courts' acceptance of customary claims, especially those concerning recreation, suggested a rationale similar to scale economies. One example was the customary right claimed by some communities to hold periodic dances, a custom held good over a landowner's objections. ${ }^{274}$ At least within the community, the more persons who participate in a dance, the higher its value to each participant. Each added dancer brings new opportunities to vary partners and share the excitement. British cases reveal other sporting and festive events that appeared to be part of some regular community gatherings. ${ }^{275}$ Activities of this sort may have value precisely because they reinforce the solidarity

${ }^{271}$ For an elegant statement of this argument, see excerpts from John W. Davis's brief cited in Mahon v. Pennsylvania Coal Co., 260 U.S. 393, 401-02 (1922) (analogizing railroad rates and rent control to eminent domain power).

$272 \mathrm{H}$. ADAMS, supra note 32, at 98-114 (describing natural monopolies and reasons for their regulation).

273 Id. at 114.

${ }^{276}$ Abbott v. Weekly, 1 Lev. 176 (17 Car. II), 83 Eng. Rep. 357 (K.B. 1665); Hull v. Nottinghan, 33 L.T.R. 697 (Ex. D. 1876).

${ }^{275}$ Hull v. Nottinghan, 33 L.T.R. 697 (Ex. D. 1876) (custom to use plaintiff's land for maypole dance and other recreation); Tyson v. Smith, 9 Ad. \& E. 406, 112 Eng. Rep. 1265 (Ex. Ch. 1838) (same for custom to put up food booths \& tables at annual fair); see, e.g., Mounsey v. Ismay, 1 Hurl. \& Colt. 729, 158 Eng. Rep. 1077 (Q.B. 1863) (same for horserace on Ascension Day); Fitch v. Rawling, 2 H. Black, 393, 396, 126 Eng. Rep. 614, 615 (K.B. 1795) (same for custom to play cricket on plaintiff's land). The 18th-century writer Thomas Blount recounted a number of customary British festivals that related back to celebrated incidents in the community's past. See Thomas Blount, Fragmenta Antiquitatis; or ANTIEnT Tenures of Land and Jocular Customs of Some Mannors 154 (1679) (custom at Burford to commemorate battle fought in 750; populace made a dragon every year and carried it about town on Midsummer Eve "in great jollity"). 
and fellow-feeling of the whole community; thus the more members of the community who participate, even if only as observers, the better for all.

In a sense, this is the reverse of the "tragedy of the commons": it is a "comedy of the commons," as is so felicitously expressed in the phrase, "the more the merrier." Indeed, the real danger is that individuals may "underinvest" in such activities, particularly at the outset. No one, after all, wants to be the first on the dance floor, and in general, individuals engaging in such activities cannot capture for themselves the full value that their participation brings to the entire group. Here indefinite numbers and expandability take on a special flavor, relating not to negotiation costs, but to what I call "interactive" activities, where increasing participation enhances the value of the activity rather than diminishing it. ${ }^{276}$ This quality is closely related to scale economies in industrial production: the larger the investment, the higher the rate of return per unit of investment.

Of course, increasing returns to scale were not an obvious feature of all customary rights. One might think that many customary activities prior to the eighteenth-century enclosures-such as cutting peat or grazing animals on commons-involved consumptive uses in which each participant's use diminishes opportunities for the others. Recent economic history suggests, however, that even these traditional activities produced economies of scale: the commons were an integral part of a mixed economic pattern in which (because of limited markets) labor-intensive individual cultivation and scale-economy commons livestock management were necessarily practiced together. ${ }^{277}$

Some version of scale returns-greater value with greater participation-thus was a dominant feature in customary commons, and indeed scale returns also cast new light on nineteenth-century

278 Some alternative terms from economic literature are "network" or "system scale economies," see David, Clio and the Economics of QWERTY, 75 Am. Econ. REv. (Papers and Proceedings) 332, 335 (1985) (referring to advantages of common typewriter keyboard), or "interdependent demand," see Rohlfs, $A$ Theory of Interdependent Demand for a Communications Service, 5 Bell J. Econ. \& MGMr. Scr. 16 (1974) (referring to enhancement of demand with greater numbers of users of communications system).

${ }^{277}$ See C. Dahlman, supra note 156, at 6-8, 124-25. On this theory, it was the expansion of trade in the sixteenth and eighteenth centuries, and the attendant possibilities for specialization, that put pressure on the elements of this mixed economy to separate, and that made feasible the individual ownership and "enclosure" of formerly common fields. $I d$. at 163-68; cf. G.E. Mingay, English Landed Society in the Eighteenth Century 179 (1963) (most enclosures occurred where agricultural specialization was possible due to access to markets). 
doctrines of inherently public property-particularly in conjunction with the holdout problem. Suppose that a private individual owned a traditional festival ground and that, at least for the festival day, the local residents placed a higher value on this festival use than could be taken from any alternative uses. Ownership of this unique property would give the owner a classic opportunity for rent capture.

But what created the "rent"? The very "publicness" of the festival use; its non-exclusivity makes it valuable, because this activity is exponentially enhanced by greater participation. This value is what customary doctrines refused to permit a private owner to tap or to thwart. In fact, the usual rationing function of pricing would be counterproductive here: participants need encouragement to join these activities, where their participation produces beneficial "externalities" for other participants. ${ }^{278}$

This juxtaposition of the elements of customary doctrine-a possibility of holdout and some version of returns to scale or "interactiveness" of use-offers new insights into the American public property doctrines for roads and waterways. Customary recreation and festivals quite clearly had an upper boundary on "interactiveness." Recreation and festivals have meaning and special social value for a given community, not for the world at large. Indeed, outsiders might make a mockery of the local festivals; they could not know the rules, and were not part of the group whose behavior could be kept in line by local customs, gossip, and social interaction with neighbors. ${ }^{279}$ Perhaps in recognition of this, the old cases accorded customary rights to dance and participate in sports only to residents of a community, and not to outsiders who chanced to be there. ${ }^{280}$

But there was no such upper boundary on commerce. According to classical economists, commerce is an interactive practice whose exponential returns to increasing participation run on without limit. The more people who engage in trade, the greater the

${ }^{278}$ For a similar problem of encouraging a "critical mass" of initial subscribers to a communications system, see Rohlfs, supra note 276 , at 28-29, 29-30, 32-37.

279 For a description of the importance of custom, gossip, and social interaction in a contemporary California community, and the disruption caused by outsiders, see Ellickson, supra note 174, at 677-78.

${ }^{280}$ See, e.g., Fitch v. Rawling, 2 H. Black. 393, 396, 126 Eng. Rep. 614, 615 (K.B. 1795) (custom to play sports was good for parish inhabitants, but not for outsiders). Another reason for the limitation no doubt related to the requirement that customs be "reasonable," which seemed to relate to preservation of the underlying resource; a custom good for all inhabitants might have pressured the resource too much. See supra text accompanying notes $156-58$. 
opportunities for all to make valuable exchanges; and the more exchanges, the greater the opportunities for division of labor and all the attendant increase in wealth and productivity that Adam Smith told us about. ${ }^{281}$ The great commerce clause cases of the Marshall court reflect the same view: a state cannot "privatize" commerce for the benefit of its own citizens, but must leave commerce open to the entire nation. ${ }^{282}$ Through ever-expanding commerce, the nation becomes ever-wealthier, and hence trade and commerce routes must be held open to the public, even if contrary to private interest. Instead of worrying that too many people will engage in commerce, we worry that too few will undertake the effort.

It is now clear why doctrines of the "inherent publicness" of roads and waterways accompanied the very ascendancy of classical economics, which otherwise placed so high a value on exclusive ownership. As Adam Smith well knew, commerce requires the interaction of persons, and this requires access to certain physical locations, namely waterways and roads. ${ }^{283}$ The individuals involved in commerce help themselves, but they help others as well, and they need encouragement to do so; thus the cost of the locations necessary for commerce-particularly transport facilities-should be kept at a minimum, and perhaps be borne by the organized community at common expense. Nineteenth-century doctrine attempted to maintain public access to these locations, even at the expense of exclusive ownership rights. It was, after all, the "publicness" of commerce-the increasing returns from greater participation-that attached an ever-increasing value to a road or waterway, beyond any alternative use of the property; and private owners could not be permitted to capture the rents created and enhanced by commerce itself. In an odd Lockeanism, the public deserved access to these properties, because "publicness," nonexclusive open access, created their highest value.

The doctrines of custom, then, tell us why certain kinds of property-particularly those necessary to commerce-were presumed to be more valuable if access were open to all. Thus holdout

283 A. SMith, supra note 6 , at 7-16.

${ }^{282}$ Gibbons v. Ogden, 22 U.S. (9 Wheat.) 1 (1824) (invalidates exclusive privilege to navigate New York waters with steam vessels). Johnson's concurrence was emphatic on the incapacity of a state to privatize navigation, and unlike Marshall's opinion did not rely on the preemptive effect of federal statute. Id. at 231-32. For more modern case law, see, for example, Sporhase v. Nebraska ex rel. Douglas, 458 U.S. 941, 953-54 (1982) (water is an article of commerce for purposes of the commerce clause).

${ }^{283}$ A. SMITH, supra note 6 , at $17-19,682$. 
may have been a necessary prerequisite to asserting public rights in property, but the public's own contribution to the property's value added a sufficient reason to do so. The publicly-created rent established a public entitlement to access. This entitlement underlay not only inherently public property, but eminent domain powers and police powers as well.

\section{Inherently Public Property, Eminent Domain, Police Power}

The public right to "its" rent could assume several guises. An organized public could use eminent domain powers, paying for the underlying land at fair market value but appropriating to itself any additional rent created by the nonexclusiveness and expandability of the public use. The "unorganized" public, on the other hand, fell back on doctrines of inherently public property-publ-ic trust and public prescription. These doctrines allocated to the public only an easement for access; but the easement again rendered to the public its rent. Thus eminent domain and inherently public property were only variant assertions of the same public entitlement to the rents that publicness had created.

With regard to the police power, nineteenth-century theorists saw as its chief concern those enterprises with economies of scale, or "natural monopolies"-the railroads, the grain elevators, etc.-where greater consumption created lower costs or higher average value per unit of production. ${ }^{284} \mathrm{Here}$, too, public regulation was meant to prevent private owners from capturing the "rent" created by "publicness": any values above opportunity costs were due to the increasing scale return of public use, and belonged to the public that created them. More railroad tickets meant that everyone could pay less per ticket; monopoly prices would only discourage what should instead be encouraged-additional participation in a market where that participation enhanced values for everyone.

In contrast to the travel and transport uses safeguarded by public property doctrines, the public rights vindicated by the police power did not necessarily require access to particular physical locations. But industries with increasing scale economies also

${ }^{284} \mathrm{H}$. AdAMs, supra note 32, at 109-14 (control of "natural monopoly"-enterprises with increasing returns to scale-is the proper subject of the police power). The classic case is Munn v. Illinois, 94 U.S. 113 (1877), permitting rate regulation of grain storage facilities on grounds that they were virtual monopolies, which is discussed in Scheiber, supra note 42, at 356 (Justice Bradley explained Munn as regulation of a monopoly that could exact tribute from the public). 
presented the possibility of holdout or monopoly pricing. ${ }^{285}$ Thus we find once again the possibility of holdout combined with a "rent" that grew exponentially larger as more persons consumed the products. ${ }^{286}$ Here too "publicness" created the rent, and from this derived the public's entitlement to reappropriate that rent when threatened with private holdout. ${ }^{287}$

Moreover, in police power as in public property doctrines, commerce played a central role. For nineteenth-century doctrine, the most important function of "inherently public property" was the protection and expansion of routes needed for the public's commercial enterprises: commerce permeated the concept of "navigability" that defined public waters, and commercial use was a central factor in determining whether a roadway was "dedicated" to the public. But commerce was also at the core of the police power, particularly insofar as that power vindicated rights of property-its major role, according to some commentators. ${ }^{288}$ If a system of property rights is a common "meta-property,"288 it was through the police power that the organized public vindicated its meta-property. Like other public property, a system of property rights has obvious returns to scale for a commercial people; it be-

${ }^{285}$ See supra note 284.

${ }^{286}$ Every enterprise should have some limit on economies of scale, some point of diminishing returns, but in the case of a "natural monopoly" product, that limit is not reached until some production point beyond demand for the product-hence increasing use continues to increase returns.

${ }^{287}$ Nineteenth-century doctrine also accorded to the police power the ability to abate public nuisances: smoke, widespread health hazards, and so on. To some degree these too concerned subjects where there are in a sense "negative economies" of scale: an individual illness causes personal hardship, but the spread of an epidemic causes exponentially larger harms-panic, shutdown of work force, etc. Moreover, individual transactions among all the persons subject to, say, railroad smoke and noise would have presented enormous negotiation problems. Instead, 19th-century governmental bodies acted as the "owners" of rights to create widespread health hazards, often abating but sometimes expressly authorizing public nuisances. For an example of the authorization of a public nuisance, see Richards v. Washington Terminal Co., 233 U.S. 546, 551 (1914) (distinguishing private nuisances, which are actionable by private individuals).

Nineteenth-century regulation of corporations may have also been based on an intuition of scale economies in raising funds, not merely on the fear of corporations' limited liability. Enterprises financed with large aggregations of capital are different in kind from a large number of smaller enterprises; thus larger funds might be more valuable than several small funds having the same aggregate value. See A. SMrTh, supra note 6, at 699-700 (joint stock companies can raise more money than partnerships); id. at 714 (they should only be permitted where an undertaking requires more funds than could be raised by partnership, e.g., banks, insurance, waterworks).

${ }^{283}$ See, e.g., J. BeNThaM, supra note 6, chs. 7-10 (law and property are co-terminous, function of law is to protect security of property, in order to encourage labor and wealth).

${ }^{289}$ See supra note 174 and accompanying text. 
comes more valuable as more participate and as all rights-holders can enter into commercial transactions with each other. In this sense, then, a property rights regime is in itself as much "inherently public property" as roads and waterways carrying public commerce; and the public protects its "meta-property" through the police power.

Nineteenth-century jurists had a propensity to slide easily between police power and public property terminology, as for example in the License Cases, which used a formulation that the historian Harry Scheiber described as a "blunt instrument".290 the police power, said Chief Justice Taney, is the authority of "every sovereign to the extent of its dominions."201 This definition seems considerably more precise when we take into account the connections between publicly-created rents and public rights-between values created by publicness and the things that the public inherently "owns." Taney's formulation is precisely in keeping with my suggestion that the subject matter of the police power was the realm of things that in some senses belonged to the public, because publicness created their value.

It was thus no accident that when the classic police power case, Munn $v$. Illinois, established the regulability of enterprises "affected with a public interest," it quoted at length from Sir Matthew Hale's treatises on those quintessential public properties, waterways and seaports. ${ }^{292}$ Police power regulation mirrored public property doctrine (and eminent domain doctrine), which claimed for the public the rent created through the openness of travel routes to an infinitely expanding commerce. By the same token, Justice Field in Illinois Central made perfect sense in equating the inalienability of the public trust with that of the police power:"293 each concerned a public "easement" over otherwise private property-an easement which cannot be bargained away to private individuals by governments or anyone else. ${ }^{204}$ Moreover, the suggestion of some modern critics that public trust doctrine does nothing that cannot be done by the police power now hardly seems surpris-

200 Scheiber, supra note 10 , at 221-22.

291 License Cases, 46 U.S. (5 How.) 504, 583 (1847).

${ }^{202}$ Munn v. Illinois, 94 U.S. 113, 126-27 (1877) (quoting from MatThew Hale, De JuRE Maris regarding ferries on public waters, and DE PoRTIBUS Maris concerning commercial wharf having natural or artificial monopoly); see also id. at 131-32 (stressing that the warehouses in the case had significant effects on the flow of commerce).

203146 U.S. 387 (1892).

204 Id. at 453. 
ing. ${ }^{295}$ These concepts shared the same concern: the prevention of private rents on activities involving increasing returns to scale. ${ }^{296}$

The activity that was most clearly public, in the sense of bringing forth infinite returns to expanding participation, was commerce. Commerce itself necessitated a private property regime and a public police power to serve it, just as commerce required some otherwise private property to be held open to the public.

\section{Implications and Conclusions: Commerce, Sociability, and Historic Change in Public Property Doctrine}

We have now worked through the major features of "inherently public property," the jus publicum, of nineteenth-century doctrine. The "public" in question was the "public at large"; sometimes it acted through organized governments, but it was also capable of acting through the medium of the customs and habits of a civilized citizenry. For this public to claim property, two elements were essential: first, the property had to be physically capable of monopolization by private persons-or would have been without doctrines securing public access against such threats. Second, the public's claim had to be superior to that of the private owner, because the properties themselves were most valuable when used by indefinite and unlimited numbers of persons-by the public at large. Publicness created the "rent" of the property, and public property doctrines-like police power doctrines-protected that publicly created rent from capture through private holdout.

The protection of commerce was clearly the central object of earlier "inherently public property" doctrines. Commerce, of all activities, is ever more valuable as more participate: markets expand and create opportunities for specialization, and we all become exponentially richer as more of us "truck, barter, and exchange."297 Commerce's primacy as a foundation for public property is thus perfectly logical, and falls into place with the very classical economic thinking that, for the most part, requires that property be separately held.

${ }_{205}$ See, e.g., Lazarus, supra note 18, at 674 (modern police power supplants public trust conceptions of public ownership); see also Jawetz, supra note 40 , at 473 (federal regulatory authority over public lands is adequate, so "public trust" doctrine is not needed).

${ }^{288}$ Modern public choice literature suggests why legislators might have different motivations from their constituencies, and thus might be tempted to make deals that effectively favor their own preferences above those of their constituencies. See Buchanan, supra note 267, at 13-14. This in turn suggests a rationale for imposing "public trust" responsibilities on legislators.

${ }^{287}$ A. SMirh, supra note 6, at 13. 


\section{A. Commerce and Sociability}

The capacity to expand wealth is not the only basis for thinking of commerce as an interactive practice, however. Eighteenth and nineteenth-century commentators thought that commerce had other interactive virtues as well, most notably that it was an educative and socializing institution. This view has been made stunningly clear by Albert Hirschman, who reminds us that eighteenthcentury economic thinkers hoped to use human avarice as the very basis for sociability. ${ }^{298}$ In comparison to the typical aristocratic (but violent) pursuits of honor and glory, commerce was thought to spring from calmer passions, ${ }^{299}$ a nation of merchants would scarcely reach to its weapons at slight provocations. Indeed, some thought the whole regime of private property and commercial enterprise aimed at disarming social conflict. ${ }^{300}$ James Madison-not to speak of more recent political economists-thought that commerce would lessen social frictions by making everyone richer, and that the wider world of trade would distract citizens from private grievances. $^{301}$

Even more important is a quality that goes beyond mere conflict avoidance: "doux commerce" was thought to make manners more gentle and stable, and to focus people's attention on the wants of others. ${ }^{302}$ Eighteenth-century commercial activity has even been linked with the development of philanthropy, because commercial enterprise enabled its practitioners to feel sensitivity and responsibility for remote persons, and gave them the sense of efficacy in dealing with the plights of others. ${ }^{303}$

28s Albert Hirschman, The Passions and the Interests 49-66 (1977).

299 Id. at $56-66$.

${ }^{300}$ See, e.g., 2 W. Blackstone, supra note 1 , at *4 (individual ownership necessary to avoid "innumerable tumults" arising from many persons striving to use the same object); $i d$. at *7 (development of land requires separate property in lands, without which "the world must have continued a forest, and men have been mere animals of prey").

sol See Diamond, The Federalist, in L. Strauss \& J. Cropsey, History of Political Philosophy 573, 590-92 (1963) (Madison favored commercial development as a means to fragment warring factions). Alexander Hamilton, however, may have been less sanguine about the possibility that commerce would lead to peace. See Gerald Stourzh, Alexander Hamilton and the IDEA of Republican Government 150 (1970). For a modern economist's interesting version of the argument that commerce dissipates social conflict, see Demsetz, Professor Michelman's Unnecessary and Futile Search for the Philosopher's Touchstone, 24 Nomos 41, 46 (1982).

${ }^{\mathrm{so2}}$ A. Hirschman, supra note 298, at 58-63; Hirschman, Rival Interpretations of Market Society: Civilizing, Destructive, or Feeble?, 20 J. Econ. Literature 1463, 1464-66 (1982).

${ }^{303}$ For a recent argument that the emergence of 18 th-century commerce was linked to humanitarianism, see Haskell, Capitalism and the Origins of the Humanitarian Sensibility 
Commerce still seems to be our quintessential mode of sociability. Despite its appeal to self-interest, it also inculcates rules, understandings, and standards of behavior enforced by reciprocity of advantage. ${ }^{304}$ To do business one must learn the ways and practices of other businesspeople; and, arguably, doing business can make even the hard-bargaining trader more accustomed to dealing with strangers, and more ready to sympathize with them and feel responsibility for their needs. ${ }^{305}$ Seen in this light, the "unorganized" public of commerce is no more an unruly mob than the community using the village green to dance; it too is a community organized by custom, albeit a community that we like to think is capable of infinite expansion. ${ }^{308}$ And like the dancers on the green, the more members of the community that are engaged in commerce, the better-not only for the sake of greater productivity, but also for the sake of socialization and the inculcation of habits of considering others.

This perhaps overly roseate Enlightenment view of commerce provides a different perspective on the "returns to scale" protected by our public property doctrines: perhaps our most important "returns to scale" involve activities that are somehow sociable or socializing-activities that allow us to get along with each other. When one begins to think of scale returns in this sense, other practices and activities besides commerce come easily to mind. Education is one important example: the value of one's own liberal education is enhanced when others are also educated, so that one can share and exchange ideas. ${ }^{307}$ Good manners are another example: one person's politeness is valuable when reciprocated (but dis-

(part 2), 90 AM. HIST. REv. 547, 550, 555-63 (1985) (trade and commerce enhanced sense of efficacy, responsibility over wider sphere, and hence sense of duty to remote strangers). See also Joyce Appleby, Capitalism and a New Social Order: The Republican Vision of the 1790 's, at 87 (commerce seen by early republicans as expanding horizons).

304 Robert Axelrod, The Evolution of Cooperation 60 (1984) (quoting Martin Mayer, The Bankers, 280 (1974)).

${ }^{\text {sos }}$ Haskell, supra note 303, at 555-56, 562; cf. J. Pocock, supra note 172, at 497-98, 502 (some Scottish enlightenment thinkers, particularly Hume and Smith, were ambivalent about the effects of commerce on character).

${ }^{308}$ It was not always thought that the commercial community was infinitely expandable; Haskell discusses the pre-18th-century view that the merchants could not trust strangers, but only those of similar family or religious ties-a view that changed in the 18th century, with the generalization of promise-keeping moral and legal norms. Haskell, supra note 303 , at 555-56.

${ }^{307}$ But some education-e.g., particular marketable skills-may be more valuable to individuals if access is limited. See, e.g., Pashigian, The Market for Lawyers: Determinants of the Demand for and Supply of Lawyers, 20 J.L. \& EcoN. 53, 80 (1977) (rate of return to legal education is high due to slow supply adjustment to higher demand). 
tinctly disadvantageous when not reciprocated). ${ }^{308}$ Commemorative practices may have this quality: one values one's honoring of some great event all the more because others do so as well; as United States v. Gettysburg Electric Railway eloquently reminded us a hundred years ago, the commemoration of a great battle would not have been so valuable had it not been shared by all at common expense-nor would it have been so poignant anywhere other than the battlefield itself. ${ }^{309}$ And generally speaking, practices that enhance the sociability of the practitioners have greater returns with great scale: one cannot get too much of them. If the inherently public property doctrines protect not just commerce, but socializing activities in general, we should expect that other socializing activities might also give rise to inherently public property insofar as those activities require certain specific locations.

\section{B. Sociability and Historical Change in Inherently Public Property}

The example of commerce is a reminder that our high regard for any particular socializing practice is an historical phenomenon. Prior to the seventeenth century, political thinkers would not have dreamed that commerce could be a socializing activity, with infinitely increasing returns to sociability. Quite the contrary: commerce was thought an activity that tended to avarice and meanspiritedness. While trade was necessary for the body politic, its practice definitely should be confined to a particular class-and a disparaged one at that. ${ }^{310}$ Even Adam Smith seems to have had doubts about the long-term effects of commerce on character and, derivatively, on society. ${ }^{311}$

Given the possibility of historical changes in activities that we

sos See, e.g., R. AxelRod, supra note 304, at 35; Schelling, On the Ecology of Micromotives, 25 The PuB. INTEREsT 59, 71 (1971) (unreciprocated cooperation may be victimized).

so9 See United States v. Gettysburg Elec. Ry., 160 U.S. 668, 681-83 (1896) (sacrifices of the Civil War are appreciated even more when commemorated at public expense). Joseph Sax has recently identified a "bandwagon" effect including matters as trivial as fashion, wherein the individual valuation of an item increases because others value the same thing. See Sax, Some Thoughts on the Decline of Private Property, 58 WASH. L. REv. 481, 486-87 (1983) (arguing also that community commitment to preservation of wilderness reinforces individual commitment).

s10 R.H. Tawney, Religion and the Rise of Capitalism 31-35 (1926) (commerce thought demeaning during medieval period, and had to be confined to one class); see also Little, Pride Goes Before Avarice: Social Change and the Vices in Latin Christendom, 76 AM. Hrst. Rev. 16 (1971) (describes avarice as taking lead over pride as the vice perceived as most dangerous in later medieval Europe).

s1' See J. Pocock, supra note 172, at 502; A. Hirschman, supra note 298, at 104-08. 
think are valuable socializing institutions, we might expect that our views of "inherently public property" would also change over time. Indeed, we should recall that the Romans had a category of public property for religious structures and places; ${ }^{312}$ this makes sense in a society that regards religion as a "social glue" that holds the whole together. Perhaps an important social glue of our own society is free speech rather than religion. Speech helps us rule ourselves; the more ideas we have through free speech the more refined will be our understanding and the better our selfgovernance. ${ }^{313}$ Thus it is not surprising to find that in recent years, there are hints that property used for political speech has come to be viewed as inherently public. In Members of City Council $v$. Taxpayers for Vincent, ${ }^{\mathbf{3 1 4}}$ for example, Justice Brennan suggested in dissent that certain publicly owned properties-here, utility poles-are uniquely suitable for the dissemination of political speech, and should be held open to the "time-honored" practice of posting signs. ${ }^{315}$ This could be stated as a public trust concept: this property is needed for the public's political communication, thus governments hold the property in "trust" for this communication, and have only limited abilities to divest the public of its trust rights. ${ }^{316}$

Free speech therefore might take a place alongside commerce as a socializing practice for our society-a practice with infinite returns to scale, whose necessary locations might be subject to a public trust. Certainly Holmes drew the analogy in his famous reference to the "marketplace of ideas." 317 To be sure, not all socializing activities-politeness, for example-require particular locations; they are thus not likely to be subject to holdout, and lack the first criterion for inherently public property. But some activities do re-

${ }^{312}$ Coquillette, supra note 9 , at 802 n.194 (res sacrae a Roman law category of public property); see also P. RIESENBERG, supra note 71, at 49-56 (discussing continued restraints on alienation of religious property in medieval ecclesiastical doctrine).

s1s See, e.g., New York Times v. Sullivan, 376 U.S. 254, 270 (1964).

314104 S. Ct. 2118 (1984).

318 Id. at 2136-37 (Brennan, J., dissenting).

316 For the idea of a protected "public forum," see United States v. Grace, 461 U.S. 171, 177-78 (1983); see also Hague v. CIO, 307 U.S. 496, 515-16 (1939) (streets and parks "held in trust" for public use for assemblies, discussion of public issues). In Vincent, the majority agreed that some property was a public forum, but denied that utility poles were necessarily or traditionally used as a public forum: $104 \mathrm{~S}$. Ct. at 2133 (poles not "uniquely valuable" as a mode of communication); $i d$. at 2134 (poles not subject to a "traditional right of access"). For what might be thought an extension of a public trust for political speech to private property, see PruneYard Shopping Center v. Robbins, 447 U.S. 74 (1980) (upholding state decision requiring private shopping center to provide access for speech and petition).

${ }^{317}$ Abrams v. United States, 250 U.S. 616, 630 (1919) (Holmes, J., dissenting). 
quire certain places, and perhaps speech is among them. This view might have reinforced the nineteenth-century notion that squares were or could become "inherently public" places. ${ }^{318}$

But what about recreation, and specifically, what about the beach cases with which we began? Certainly the role of recreation is a striking example of historic change in public property doctrine. ${ }^{319}$ If recreation now seems to support the "publicness" of some property, this undoubtedly reflects a change in our attitudes toward recreation. We might suspect that this changed attitude relates to an increasing perception of recreation as having something analogous to scale returns, and as a socializing institution.

Recreation is often carried on in a social setting, and therefore it clearly improves with scale to some degree: one must have a partner for chess, two teams for baseball, etc. But in the midnineteenth century, Frederick Law Olmsted argued that recreation had scale returns in a much more expansive sense: recreation can be a socializing and educative influence, particularly helpful for democratic values. ${ }^{320}$ Thus rich and poor would mingle in parks, and learn to treat each other as neighbors. ${ }^{321}$ Parks would enhance public mental health, with ultimate benefits to sociability; all could revive from the antisocial characteristics of urban life under the refining influence of the park's soothing landscape. ${ }^{\mathbf{3 2 2}}$ Later recreation and park advocates, though moving away from Olmsted's more contemplative ethic, also stressed the democratic education that comes with sports and team play. ${ }^{323}$

Insofar as recreation educates and socializes us, it acts as a "social glue" for everyone, not just those immediately engaged; and of course, the more people involved in any socializing activity, the

31 See supra text accompanying notes 198-99.

s1s See supra text accompanying notes 203-29.

sso Frederick Law Olmsted, Civilizing American Cities: A Selection of Frederick Law Olmsted's Writings on City Landscapes 74-81 (S. Sutton ed. 1971).

321 Id. at 75-77; see also Blodgett, Frederick Law Olmsted: Landscape Architecture as Conservative Reform, 62 J. AM. HIST. 869, 878 (1976); Cranz, The Changing Role of Urban Parks, LANDSCAPE, Summer 1978, at 9, 11.

${ }_{322}$ F. Olmsted, supra note 320, at 65-66, 96; see also Higginson v. Treasury, 212 Mass. 583, 590, 99 N.E. 523, 527 (1912) (park is public good because it is "civilizing" in the context of urban congestion); Roderick NASH, Wilderness aND the AMERICAN Mind 106-07 (rev. ed. 1973) (discussing Olmsted's arguments for preserving Yosemite). Nash's book places Olmsted and wilderness preservation generally in a contemplative tradition that goes back to the early Christians and (somewhat later) Petrarch. Id. at 17-20.

s2s See Cranz, supra note 321, at 12-15. For a modern-day version of the conflict between contemplation and active play, see Futrell, Parks to the People: New Directions for the National Park System, 25 EMORY L.J. 255, 269-72, $277-78$ (1976) (describing conflicts over the role of the National Park Service in urban parks). 
better. Like commerce, then, recreation has social and political overtones. The contemplation of nature elevates our minds above the workaday world, and thus helps us to cope with that very world; recreational play trains us in the democratic give-and-take that makes our regime function. ${ }^{324}$ If these arguments are true, we should not worry that people engage in too much recreation, but too little. This again argues that recreation should be open to all at minimal costs, or at costs to be borne by the general public, since all of us benefit from the greater sociability of our fellow citizens. If we accept these arguments, we might believe that unique recreational sites ought not be private property; their greatest value lies in civilizing and socializing all members of the public, and this value should not be "held up" by private owners. ${ }^{325}$

These arguments support the recent decisions defending public access to the beach. The public's recreational use arguably is the most valuable use of this property and requires an entire expanse of beach (for unobstructed walking, viewing, contemplation) which could otherwise be blocked and "held up" by private owners. But are these beach recreation areas really comparable to town squares, or to the Gettysburg monument-not to speak of commercial transportation routes? Do they serve a democratizing and socializing function that can be compared to commerce or speech, that becomes ever more valuable as more people are involved? Do people using the beach really become more civil, or acquire the mental habits of democracy? ${ }^{326}$ And even if they do, is there really a danger of holdout that necessitates inalienable public access?

324 Blodgett, supra note 321 , at 877 , and Cranz, supra note 321 , at 9 , take a somewhat less sanguine view of the park movement, arguing that it was an effort at social control, aimed at allaying lower class discontent.

s2s This does not mean that everyone must be allowed to use the same facilities concurrently-on the contrary, recreational resources clearly need some management and rationing. But some recreational activities should be open to all, and without substantial charge.

${ }^{328}$ See supra note 324. There are of course other justifications for governmental purchase or ownership of beach property, namely that all the individuals among the governed, taken in the aggregate, value the beach more than all private owners, and the governmental body merely acts as their agent in a deal that would otherwise be difficult to arrange. See, e.g., Calabresi \& Melamed, supra note 188, at 1106-08 (using parks as an example). Similar arguments could be (and have been) made for the public's retention and management of other public lands and properties. See, e.g., Sax, supra note 18, at 560-61 (chief purpose of public trust doctrine is to overcome underrepresentation of diffuse interests). These "governmental brokerage" arguments are different from the "interactive" or "scale return" arguments historically used to impose a public trust on property, where wider use exponentially increases the value of the underlying property. Indeed, the brokerage arguments sometimes seem to lack a justification for thinking that members of the public do place a high value on, for example, national parks; in that sense they may implicitly presuppose some argument of "inherent publicness" similar to scale returns. 
Attractive as this Olmstedian view may seem, these are not always easy arguments to support, and are extraordinarily difficult to prove. The argument that recreation or the contemplation of nature makes us more civilized and sociable has a very long pedigree in Western thought. ${ }^{327}$ Moreover, it may seem particularly attractive as our confidence has waned (perhaps somewhat unjustifiably) in the socializing qualities of commerce. ${ }^{328}$ With respect to the holdout problem, one might be skeptical and think that where waterfront owners are numerous, they cannot really siphon off the value of expansive public uses. ${ }^{329}$ But whether or not one accepts these arguments in the modern beach debate, older doctrine suggests that the "scale returns" of socialization, taken together with the possibility of private holdout, will underlie any arguments for the inherent publicness of property.

Perhaps the chief lesson from the nineteenth-century doctrines of "inherently public property," then, is that while we may change our minds about which activities are socializing, we always accept that the public requires access to some physical locations for some of these activities. Our law consistently allocates that access to the public, because public access to those locations is as important as the general privatization of property in other spheres of our law. In the absence of the socializing activities that take place on "inherently public property," the public is a shapeless mob, whose members neither trade nor converse nor play, but only fight, in a setting where life is, in Hobbes' all too famous phrase, solitary, poor, nasty, brutish, and short.

${ }^{327}$ See R. NASH, supra note 322 (long history of association of wilderness with contemplation).

s28 See J. APPLEBY, supra note 303, at 104-05 (1984) (current distrust of commerce). No doubt some of our diminished trust in the socializing capacities of commerce stems from the Marxist attack on the divisiveness of competitive free enterprise. See A. Hirschman, supra note 298, at 62 (Marx sneered at "doux commerce"). Some also stems from an Aristotelian tradition, perhaps best represented by Tocqueville, pointing to the unsettling and isolating characteristics of commerce. See Alexis DE TOcqueviLle, 2 Democracy in America 136-37 [bk 2, ch. 13] (Bradley ed. 1945) (pursuit of material goods is accompanied by restlessness and an inability to attain satisfaction); $i d$. at 141 [bk. 2, ch. 14] (pursuit of material welfare may lead to individual neglect of public affairs). An interesting revival of the notion that constant trading leads to cooperative behavior is presented in R. Axelrod, supra note 304.

320 Here too there is a counterargument: some beaches are unique and indeed constitute a whole unit of interacting parts (dunes, grasses, etc.), where public ownership might enlarge the scope of the resource and thus tend to preserve it as a whole. This is basically an argument for enlarged, although not necessarily public, ownership, and could be analogized to arguments for the unitization of other large resources, such as oil reservoirs, for the sake of more efficient use of the resource. See, e.g., Palmer Oil Corp. v. Phillips Petroleum Co., 204 Okla. 543, 550, 231 P.2d 997, 1005 (1951). 